University of Rhode Island

DigitalCommons@URI

Open Access Master's Theses

1972

\title{
Organization and Development of a Computerized Drug-Drug Interaction File
}

Charles Daniel Mahoney

University of Rhode Island

Follow this and additional works at: https://digitalcommons.uri.edu/theses

\section{Recommended Citation}

Mahoney, Charles Daniel, "Organization and Development of a Computerized Drug-Drug Interaction File" (1972). Open Access Master's Theses. Paper 203.

https://digitalcommons.uri.edu/theses/203

This Thesis is brought to you for free and open access by DigitalCommons@URI. It has been accepted for inclusion in Open Access Master's Theses by an authorized administrator of DigitalCommons@URI. For more information, please contact digitalcommons-group@uri.edu. 


\section{ORGANIZATION AND DEVELOPMENT OF A COMPUTERIZED}

\section{DRUG-DRUG INT ERACTION FILE}

BY

CHARLES DANIEL MAHONEY

A THESIS SUBMITTED IN PARTIAL FULFILLMENT OF THE REQUIREMENTS FOR THE DEGREE OF MASTER OF SCIENCE IN PHARMACY 


\section{MASTER OF SCIENCE THESIS}

$\mathrm{OF}$

CHARLES DANIEL MAHONEY

Approved:

Thesis Committee:

Chairman

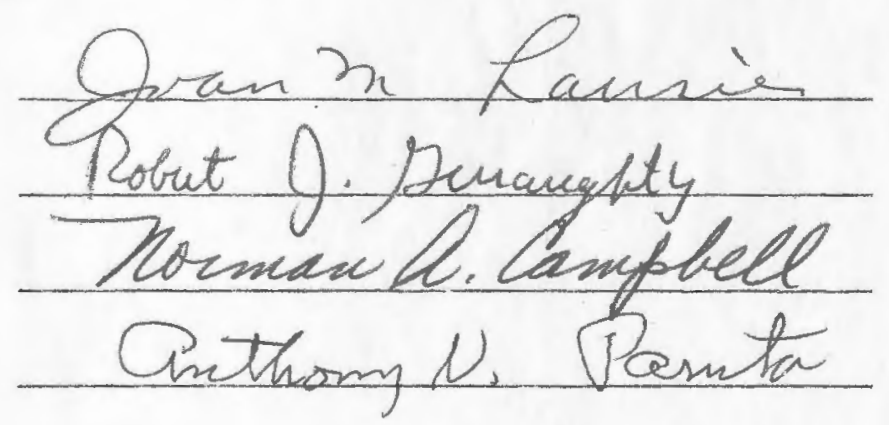

\section{Q. A. midul}

Dean of the Graduate School

UNIVERSITY OF RHODE ISLAND 
TITLE ABSTRACT

COMPUTERIZED DRUG-DRUG INTERACTION FILE 


\begin{abstract}
The project was designed to organize and develop a computerized drug-drug interaction file. The methodology for the organization, storage and retrieval of drug-drug interaction information is discussed. In order to accomplish this objective several requirements were met. They are as follows: (1) Selection and evaluation of clinically significant drug-drug interactions from the scientific literature,
\end{abstract} (2) Creation of a computerized data bank for drug-drug interactions, and (3) Design and development of a computerized printout which reports the information in concise summaries.

The file is designed to be compatible with existing computerized record keeping and drug information systems. In addition, the retrieval system has several unique characteristics. The reporting format is designed to provide practical drug-drug interaction information in a concise summary which can be easily understood and utilized by either a physician or pharmacist in a patient care environment. It will provide the clinical pharmacist with a invaluable reference to be utilized as a "key" to clinical involvement with the medical staff. The printout may be incorporated into a patient's cumulative medication profile or merely used as a reference source to screen for probable drug-drug interactions. Another unique feature of the system is that it reports important drug-drug interactions with each drug entity the patient is receiving. The system is not limited 
to the reporting of specific interactions which may occur with the patient's current therapeutic regimen.

Several illustrations are presented using the file in conjunction with a computerized medication profile system. The applications of this system provide a rational approach towards determining the probability of drug-drug interactions resulting from the concurrent administration of drugs. 


\section{ACKNOWLEDGEMENT}

The author wishes to thank Dr. Joan M. Lausier and the members of the thesis committee for their assistance in editing this manuscript. The author is especially grateful to his wife, Carolyn, for her untiring effort in the preparation of this manuscript and to Mr. Paul-Emile B. Platiau for his advice and programming assistance. 
ABSTRACT......................... i i ACKNOWLEDGEMENT. . .............

TABLE OF CONTENTS ................. vi

LIST OF ILLUSTRATIONS . . . . . . . . . . v vii

I. INTRODUCTION ................. 1

II. METHODOLOGY. . . . . . . . . . . . . . 8

III. RESULTS AND DISCUSSION . . . . . . . . . 13

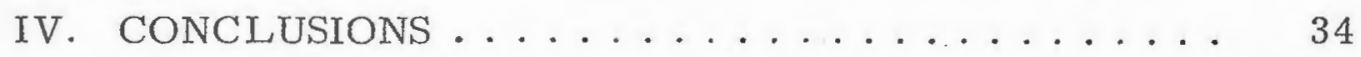

V. REFERENCES CITED ............ 36

VI. APPENDICES ............... 40

I. Source Document............. 40

II. Alphabetical Cross-Index .......... 64

IIr. Message Code Index. . . . . . . . . . . . 69

IV. Selected References. . . . . . . . . . 75

V. Drug-Drug Interaction Printout . . . . . . . 94

VI. Computer Program ............... 11 I 


\section{IIST OF ILLUSTRATIONS}

ILLUSTRATION

PAGE

I. Patient Medication Profile. Example I .......... 27

II. Patient Medication Profile. Example II .......... 30 


\section{INTRODUCTION}

In the last several years there has been an increasing awareness of drug interactions in the medical and pharmaceutical literature. The recognition of drugs that interact with other drugs is of more than passing interest because of the potential consequences of unpredicted reactions.

The phrase "drug interactions" is now part of the common terminology used in medicine and pharmacy. The phenomenon of drug interactions includes the interaction of drugs with certain foods, laboratory tests, and various underlying pathological states. The scope of this project is restricted to drug-drug interactions.

Drug-drug interaction is a phenomenon which occurs when the effects of one drug are altered by the prior or concurrent administration of another (or the same) drug (s). It presents a complex and profound problem. The means by which drug interactions occur are varied and complex. They may arise either from alteration of the absorption, distribution, biotransformation or excretion of one drug by another, or from a combination of their actions or effects.

In order to have a general understanding of drug interactions one must have a basic knowledge of a number of mechanisms. The basic causes for these interactions are as follows:

\section{Potentiation}

Drugs having similar pharmacological properties can 
be expected to potentiate one or more of the pharmacological effects in patients taking these medications.

2. Antagonism

Drugs which have opposing pharmacological effects may produce a combined effect less than that of the active compound. The basic underlying mechanism of drug antagonism may be chemical, competitive, non-competitive or physiological.

3. Alteration of Gastrointestinal Absorption Drugs may alter gastrointestinal absorption by complexation or be changing the $\mathrm{pH}$ of the gastric fluid. Since many drugs are weak acids or bases, the pH of the gastrointestinal tract will influence the extent of absorption and also the site at which absorption takes place. Drugs may form inactive or insoluble complexes with other drugs in the gastrointestinal tract. It is well known that tetracyclines can combine with di - and trivalent cations to form a complex which is poorly absorbed.

4. Stimulation of Metabolism

A number of drugs can increase the activity of liver microsomal enzymes. The enzyme stimulation results in a more rapid metabolism and excretion of other drugs 
that are simultaneously administered.

5. Inhibition of Metabolism

Drugs that can inhibit the activity of liver enzymes indirectly may increase the activity of drugs which depend on this enzyme for their metabolism.

6. Displacement of Drugs from Protein Binding Sites

A competition will exist when two or more drugs are administered concurrently which are capable of binding to proteins. The drug that has the greater affinity for the binding site will displace the other from the plasma or tissue proteins.

7. Interactions at the Receptor Site

Some drugs combine with receptors to form complexes that elicit responses (agonists). Other drugs combine with receptors and elicit no responses (antagonists): In this type of interaction the degree of response will depend on the drug and its affinity for the receptor site.

8. Alteration of Electrolyte Levels

Changes in electrolyte levels may make certain physiological systems more sensitive to the effects of a particular drug.

9. Alteration of Urinary Excretion Alteration of urinary excretion can be accomplished by 
changing the urinary $\mathrm{pH}$ or by interfering with tubular excretion. The renal tubular reabsorption of a drug can therefore be increased or decreased by another agent. The economic consequences of drug reactions are staggering. It has been reported that one seventh of all hospital days are devoted to the care of drug toxicity, at an estimated yearly cost of three billion dollars (1). Considerable attention has been focused on the increasing incidence of drug reactions. Approximately 18 to 30 percent of all hospitalized patients experience a drug reaction during their hospitalization (2). In addition, 3 to 5 percent of all admissions to hospitals are primarily due to an adverse drug reaction $(2,3)$.

It is a difficult and cumbersome task for a hospital pharmacist to accurately review all medication profiles on a routine basis for drug interactions. Hospital pharmacists in the past $(4,5,6)$ have attempted to meet this challenge by developing charts and card files specifically designed for the rapid retrieval of drug interaction information. However, this is an extremely time consuming task. Often it is a retrospective review rather than a prospective analysis. This situation has created a growing interest as well as a potential need for more efficient electronic data processing (EDP) methods designed for the retrieval and utilization of documented drug-drug interactions.

Another factor creating an interest in the field of drug inter- 
actions is the potential liability of the pharmacist and physician. The failure to avoid or notice a potentially harmful effect resulting from a drug-drug interaction can make either the physician or pharmacist a candidate for liability. If screening a patient's medication profile is a duty pharmacists accept in a particular locale, then this will undoubtedly become part of the standard of care for patients in that area (7). When such is the standard of practice the public will expect the pharmacist to perform this function carefully and prudently.

This project was undertaken to organize and develop a file of drug-drug interaction data suitable for computerization. In order to accomplish this objective several requirements were met. They are:

1. Selection and evaluation of clinically significant drugdrug interactions from the scientific literature.

2. Creation of a computerized data bank for drug-drug interactions.

3. Design and development of a computerized printout which reports the information in concise summaries. The scientific literature is replete with relevant clinical studies $(8,9,10,11)$ and isolated case reports $(12,13,14,15)$ citing drug-drug interactions. The National Library of Medicine's computer-based Medical Literature Analysis and Retrieval System (MEDLARS) compiles and produces Toxicity Bibliography which covers the adverse and toxic effects of drugs reported in approxi- 
mately 2, 300 biomedical journals. This reference is similar to other indexing and abstracting services in that they are all designed to provide a means to access the scientific literature pertaining to chemical and biological interactions. Services such as this are an important contribution towards realization of a comprehensive toxicology information system; however, they only constitute the initial phase in developing a mechanism which provides the clinician with drug-drug interaction data in a practical "ready to use" format. Multiple-drug administration is common to both hospitalized and ambulatory patients. It is extremely common for a patient to be suffering from more than one unrelated disorder which demands simultaneous treatment with two or more drugs. In such instances interactions are often unexpected. Melmon (1) reported that the average patient in a hospital receives six to ten drugs during his hospitalization. At this level of multiple-drug administration, the adverse reaction rate was reported to be 7 to 10 percent. Some patients receive more than 20 drugs simultaneously. Under such circumstances the patient has at least a 40 percent chance of having adverse reactions to one or more of the drugs. Multiple-drug therapy generally provides greater efficacy than can be achieved with full doses of single drugs, greater margin of safety, or more satis factory onset or duration of effect. In addition to the administration of drugs concurrently for their independent and unrelated effects, 
drugs are sometimes administered concurrently to make use of expected interactions. The phenothiazines markedly affect the actions of a number of other drugs. Phenothiazines are often prescribed for their ability to potentiate the effects of central nervous system depressants. It is common practice to administer a phenothiazine such as promethazine hydrochloride concurrently with a narcotic analgesic in order to reduce the dosage of the narcotic that would normally be required to produce the desired level of analgesia. 


\section{METHODOLOGY}

The scientific literature, both primary and secondary reference sources, was reviewed and evaluated for clinical significant drug interactions. Only drug-drug interactions reported in humans are included in this compilation. Drug interactions occuring only in animals or only in vitro systems have been excluded.

\section{EVALUATION PROCEDURE:}

In the assessment of drug interactions for this compilation a selected number of original references were reviewed and evaluated. Secondary references (eg. review articles, drug interaction tables, manuals, etc.) generally do not provide sufficient information on which to make an evaluation. Secondary references are useful in cross-indexing closely related drugs but not, of the same group mentioned in the primary reference source. This is an extremely complex problem since for every basic drug class (eg. barbiturates, corticosteroids, sulfonamides) there are many similar generic drugs which closely resemble the parent compound. In order for a drug interaction compilation to be of any practical value the structure activity relationships of these various compounds have to be taken into consideration. Secondary reference sources were first evaluated on the content of the discussion and the references they provided the user before any decision was made concerning the validity of a particular drug-drug interaction listed in the text. 
The initial undertaking was to review a number of abstracting and indexing services, which included, Toxicity Bibliography, International Pharmaceutical Abstracts, Clin-Alert, and FDA:

Clinical Experience Abstracts.

In the evaluation of the primary literature for reports of drug interactions the following journals were consulted whenever possible:

1. American Journal of Psychiatry

2. Annals of Internal Medicine

3. Clinical Pharmacology and Therapeutics

4. British Journal of Anesthesia

5. British Medical Journal

6. Anesthesia and Analgesia

7. New England Journal of Medicine

8. Lancet

9. Neurology

10. Journal of Pediatrics

Isolated case reports were only considered if there was some conclusive documentation cited in the literature. Generally speaking, it is extremely difficult if not impossible, to differentiate a case report of a suspected drug interaction from a idiosyncratic or hypersensitive reaction attributable to one of the active components in the multi-drug therapy. What further complicates a literature search for drug interactions is that there are few accepted scientific 
studies. The well-controlled clinical experiment is virtually nonexistant for obvious reasons. It is difficult for a practitioner to justify re-challenging a patient to a drug when a drug interaction is suspected. Especially if there are other drugs or therapeutic measures available to treat the condition. When there was a choice of references a number of criteria were used to evaluate the study. The general requirements for an adequately controlled study are an objective and practical (sensitivity) method of evaluation, an adequate number of subjects, lack of bias, concurrent comparison of the drug regimen in question with a reference standard, dosage variance, and appropriate statistical validation.

\section{EVALUATION CRITERIA:}

There are many factors which may modify the effects of drugs. Some of these result in qualitative differences in the effects of a drug while others produce only quantitative changes in the effects of the drug which are dose dependent. It is extremely important to evaluate a number of specific patient factors before an adverse response is attributed to a drug-drug interaction. The physiological, pathological and genetic factors which are well known to alter response to drugs and which were taken into consideration are age (infant and elderly), sex, race, body weight (nutritional state), tolerance, pathological state, metabolic differences and organ function. The specific mechanisms for these physiological states altering drug response 
are well documented in the literature $(16,17)$.

Another area of paramount importance is the variables

associated with drug dosage and route and method of administration.

Specifically these factors can be categorized as dosage, route of administration, dosage form, frequency of administration and duration of therapy.

In any defined population, response to a drug generally follows a normal distribution. That is, a few patients will be hypersensitive and will respond to a small dose while a large majority will respond best in the therapeutic range. On the other hand, a few will be relatively resistant to the effects of the drug. This. kind of response curve applies to both therapeutic effects and adverse responses which may include drug-drug interactions.

There are a number of parameters which proved helpful in determining the clinical importance of reported drug interactions. They are: occurrence (animal or human, in vivo vs. in vitro), incidence, etiology, structural activity relationships, severity of reported interaction, clinical manifestations, clinical course, prognosis and treatment.

\section{FORMAT AND INDEXING:}

This computerized drug interaction file is designed to be compatible with a number of existing computerized record keeping and drug information systems. The information in the file provides a 
concise pharmacological summary in a reporting format suitable for actual clinical use in the patient care environment.

The specific drug entities are cross-indexed to a message code. The message code was assigned from a listing of valid numbers calculated by $(5 A+4 B+3 C+2 D+E / 11=Y \times 11)$. The source document (reference document) which consists of the message codes, arranged sequentially, and the appropriate drug interaction summary was then compiled. In the source document the interactions enumerated in the summary or message are coded to one or more specific references. This particular coding system offers the user a means to obtain the specific references on which the information in the message is based.

Combination products in the top two-hundred prescribed drugs are included if one or more of the active ingredients was implicated in a drug interaction. For example, Desbutal-15 Gradumet which contains methamphetamine hydrochloride $15 \mathrm{mg}$. and pentobarbital sodium $90 \mathrm{mg}$. is assigned two different messages. The messages for barbiturates and amphetamines will be reported when the file is searched for possible drug-drug interactions involving this combination product. 


\section{RESULTS AND DISCUSSION}

The system is designed to provide the physician with important drug information on selected drug-drug interactions. In addition, and equally as important, it will provide the clinical pharmacist on the Patient Care Unit with a valuable reference to be utilized as a "key" to clinical involvement with the medical staff. The basic objective of the system is to provide the physician and clinical pharmacist with a reference source enabling him to rapidly screen a medication profile for possible drug-drug interactions. When a probable drug-drug interaction is noted, and it is definitely determined the patient is receiving both medications concurrently the clinical pharmacist may then elect to contact the physician. In certain instances it may be only necessary for him to inform the nurse of the possible interaction. For example, if a patient is receiving both an antacid preparation and bisacodyl tablets, an enteric coated laxative, the pharmacist should advise the nurse not to administer both medications simultaneously, but rather as far apart as posible.

A source document (reference document) was the first document compiled (Appendix I). A five character numeric code was assigned to each message. The specific drug entities which were coded in the source document were compiled and cross-indexed to the respective message code (Appendix II). A second index (Appendix III) was compiled listing the message codes in sequence and the par- 
ticular drugs to which the summary applies. This index is useful to the user when it is necessary to determine the complete list of 'drugs which have been indexed to any one particular message. The source document codes the specific interaction enumerated in the summary to one or more specific references thereby offering the user a means to obtajn the references on which the information is based. A list of the selected references utilized is included (Appendix IV).

A printout of the messages exactly as they were retrieved from storage is included for illustrative purposes (Appendix V). The printout included in this document represents a xeroxed copy of a computer printout which was photoreduced by twenty percent.

The following message represents an example of a summary as it was printed from the data bank:

Salicylates elevate the anticoagulant response to oral anticoagulants, increase plasma levels of unbound penicillin G and derivatives and potentiate methotrexate and sulfonylureas. Salicylate plasma levels may be decreased by corticosteroids. They may decrease serum levels of indomethacin (Indocin) and inhibit uricosuric activity of sulfinpyrazone (Anturane) and probenecid (Benemid).

If the information is of interest to the physician hopefully he will be stimulated to seek the references and request a "consultation" from the Pharmacy for further evaluation. A pharmacy consultation would consist of a pharmacist reviewing a patient's medical record in light of the drug-drug interaction information reported for a particular patient. The pharmacist would determine if the drug-drug 
interaction information is significant in that patient and whether the patient's physician should be informed of the findings. In order to accomplish efficient retrieval of the specific references which were applicable to the message, a source document (reference document) was created (Appendix I). Ideally it would be advantagious to create a file containing the hard copy of the references most frequently requested. As the number of references increase the original copy can be microfilmed and placed in a microfiche to reduce storage requirements. The previous example appears in the source document as :

04383 Salicylates

Salicylates elevate the anticoagulant response to oral anticoagulants (13), increase plasma levels of unbound penicillin G and derivatives (14) and potentiate methotrexate (16) and sulfonylureas (17). Salicylate plasma levels may be decreased by corticosteroids (15). They may decrease serum levels of indomethacin (Indocin) (53) and inhibit uricosuric activity of sulfinpyrazone (Anturane) (18) and probenecid (Benemid) (19).

Generally speaking, the reference selected for the list (Appendix IV) represents the most scientific and significant literature citation reviewed for that particular interaction. In certain instances two or more references are cited for a specific interaction. When more than one mechanism has been postulated in the literature a cross sample of references are included. For example, salicylates have been shown to displace methotrexate from plasma protein binding, thereby elevating plasma levels of free methotrexate. However, 
salicylates may also block the renal excretion of methotrexate. Therefore the increased activity of methotrexate, usually manifested by increased toxicity, is attributable to both of these mechanisms.

REPORTING FORMAT:

The reporting format is designed to provide practical information in a concise summary which can be easily understood and utilized in a patient care environment. The printout may be incorporated into a patient's cumulative medication profile or used strictly as a reference source to screen for drug-drug interactions.

A reporting format (previously illustrated) was chosen which would enable a physician or a pharmacist to effectively review a patient's previous medication history as well as the present drug the rapy for suspected drug-drug interactions. A unique advantage of this system is that it reports important drug-drug interactions with each drug entity the patient is receiving. The system is not limited to the reporting of specific interactions with the concomitant use of two drugs.

A retrospective review of a patient's previous medication history is a valuable exercise in light of the extended biological halflife of many drugs and the many structural similarites which exist. This is extremely important since so many of the reported drug interactions exhibit structure activity relationships and are not specific for any one drug entity. The sulfonamides are a class of drugs in 
which a number of the drug interactions involving these compounds are structure dependent. This information is of practical value in a patient care environment, because it provides the physician with drug interaction information which will enable him to make an intelligent choice as to the appropriate class of drugs to prescribe.

This sort of information is also helpful in predicting unknown reactions which may occur with new drugs. There are many instances when it is impossible to predict a possible drug-drug interaction based on the structure activity relationship to a parent compound. For example, a new drug with a phenothiazine nucleus would be expected to potentiate the effects of central nervous system depressants. In the majority of instances so-called new drugs are merely molecular modifications of an existing generic drug or are compounds which are transformed to a pharmacologically active compound which in itself is commercially available.

The importance of knowing beforehand when two drugs given together will result in an interaction cannot be overemphasized. Since drug interactions unknown to-date cannot be predicted in patients taking two or more drugs at the same time, only those interactions already reported in the literature offer any clue as to what drugs make a rational combination.

\section{LITERATURE EVALUATION:}

Drugs which exert a similar pharmacological action and which 
are prescribed for the same therapeutic purposes were not considered as examples of drug-drug interactions having additive or synergistic pharmacological effects (e.g. epinephrine and levarterenol). Another broad area which was not included in this file is the rationale of combining both bacteriostatic and bactericidal antibiotics in the same therapeutic regimen. Jawetz (18) has reported that antibiotic antagonism may occur but the net effect plays a minor role in clinical medicine. This has been an extremely controversial subject for years and still has not been resolved. The inclusion of this sort of material in a drug interaction compilation is of no practical value. One of the major difficulties in evaluating drug interactions is, the occurrence of contradictory reports concerning a specific interaction. For example, a drug interaction of considerable interest to neurologists is the reported inhibition of diphenylhydantoin and phenobarbital metabolism by methylphenidate. Recent studies $(19,20)$ indicate that during the period of concurrent drug administration there is no elevation in diphenylhydantoin plasma levels or clinical signs of drug toxicity. Based on the results of these two studies this suspected interaction was not included in the file. Although these studies do not preclude the possibility of an interaction of methylphenidate with the anticonvulsants they do suggest that if this interaction does exist it must occur infrequently.

A similar case is illustrated by the combination of a tricyclic 
antidepressant and a monoamine oxidase inhibitor (MAOI) in the treatment of depression. This combination is often contraindicated in the literature as well as the respective product brochure. In certain instances a medication-free period of two weeks is recommended after discontinuance of the MAOI and the institution of a tricyclic antidepressant. However, there have been two recent publications $(21,22)$ concerning antidepressant therapy which indicate that the combined use of a tricyclic antidepressant and a MAOI may not be hazardous and that this method of treatment may be used with considerable benefit to the patient. Since it was listed as a caution in the product brochure it was decided to include it in the files despite the fact that the clinical significance of this interaction has not been demonstrated.

The interaction between chloral hydrate and warfarin sodium is even more complex. In 1966 Cucinall et al (23) suggested that the coadministration of bishydroxycoumarin and chloral hydrate resulted in a reduction in expected plasma levels of the anticoagulant with a decrease in prothrombin time. Sellers and Koch-Weser (24) showed that the administration of $1 \mathrm{Gm}$. chloral hydrate for one week increased the hypoprothrombinemic effect of warfarin sodium by 40 to 80 percent. Griner, P.F., et al (25) recently conducted a study to determine the effect of chloral hydrate in patients receiving longterm therapy with warfarin sodium. Their findings, unbelievable as 
they may seem, indicated that chloral hydrate or its equivalent as chloral betaine, in doses of 0.5 to $1 \mathrm{Gm}$. daily, did not influence the anticoagulant effect of warfarin in such patients. Since the studies reported in the literature are not conclusive and the results remain contradictory it was decided to include in the file a statement to the effect that "chloral hydrate variably effects the anticoagulant response to oral anticoagulants." This statement merely points out the fact that chloral hydrate may in some way interfere with the hypoprothrombinemic effect of oral anticoagulants.

Diphenylhydantoin is one of many drugs metabolized by enzymes found in the microsomal fraction of hepatic cells. The drug phenobarbital, is known to stimulate these enzymes and thus the metabolism of diphenylhydantoin. Apparently, the ability of phenobarbital to lower plasma levels of diphenylhydantoin is not so great as to offset its own anticonvulsant activity. Although a biochemical antagonism exists the net result is a potentiation of the desired pharmacological effects. This particular combination is the drug regimen of choice for grand mal epilepsy. A suspected or reported drug interaction can not be evaluated solely on the basis of biochemical data. It must be remembered that combination drug therapy attempts to achieve one or more the rapeutic effects with a minimum of adverse effects. The ultimate clinical objective of the the rapeutic regimen must always be considered. On the other hand, this antagonism may be significant if the patient 
was receiving large doses of diphenylhydantoin (common to hospitalized patients in psychiatric hospitals) and then had the phenobarbital discontinued. In this particular case, the diphenylhydantoin plasma levels may well rise to a toxic level.

Isolated case reports (one or two patients) were excluded except the reports concerning methotrexate and small pox vaccination. Methotrexate, a antineoplastic agent, may inhibit the immunological response to smallpox vaccine resulting in generalized vaccinia. The decision to include this interaction was strictly subjective and not based on any rational scientific data. Regardless of the severity of the reaction one would not expect to find numerous cases or controlled studies since the use of this combination is very limited. An important consideration is that by reporting this interaction it may alert the prescriber to possible difficulties with other immunosupressive drugs, namely the corticosteroids.

There are a number of interactions which are well known in medical circles but specific clinical documentation is lacking. The major area of concern to the clinician is that although the clinical data is lacking they are included in the pharmaceutical brochure which brings about a potential legal liability. From a medicolegal standpoint it is wise to include these in a drug interaction file in order that the physician will be forewarned about a possible adverse effect. If the drug interaction is included in the product literature 
as a caution or warning the physician is faced with a legal dilemma. In this situation the physician may wish to select another drug or decide to run the risk to the patient. This situation is applicable to the following examples of drug-drug interactions: Propoxypheneorphenadrine, meperidine-isoniazid, and allopurinol-iron.

\section{CURRENT APPLICATIONS:}

The system is designed in a manner which enables it to be incorporated into a program using computerized medication profiles. The messages or supplementary notes pertaining to possible drugdrug interactions immediately follow the cumulative medication profile (Illustration I). In the first example (Illustration I) the information presented in the accompanying messages does not suggest any specific drug interactions with the drug regimen outlined in the medication profile. However, the information would be extremely useful to the physician if he were considering adding additional drugs to the present therapeutic regimen. The information previously presented may forewarn him of an interaction. In the second example (Illus tration II) the messages describe pertinent drug-drug interactions which are possible with the current therapeutic regimen. If a medication has been discontinued the drug interaction summary is not printed. This check is built into the computer program. For example, in Illustration I the message summary for diphenhydramine hydrochloride (an antihistamine) was printed while it was not in the 
second illustration since the drug had been discontinued.

The program of instructions designed to print the cumulative medication profile and search the drug interaction file for the appropriate drug interaction message code is included (Appendix VI). The computer program is written in COBAL.

From a practical viewpoint it is difficult to justify a computer program which does not always produce a tangible result. It is much more difficult to implement a program limited to professional objectives as opposed to a cost accounting program designed to process medication charges. As with most organizations computer time is expensive and is limited. An additional feature of the cumulative patient medication profile described in this project is that it can be used as a dispensing record for a medication distribution system.

All that is necessary to incorporate this file into an ongoing computerized system is to place the file in storage and then assign message codes to drug names listed in a computerized drug product file or a drug data file. In order to facilitate this task the specific generic entities are cross-indexed to the appropriate message codes (Appendix II). The drug product file can be compiled by the individual institution or a commercially available file can be purchased. The American Society of Hospital Pharmacists Drug Product Information File (DPIF) serves as a master drug code dictionary and is adapt- 
able to each individual system. The DPIF is a data bank composed of terms and code numbers for commercially available drug products which is organized to facilitate automated processing of drug data. This particular multi-functional drug coding system is based on a 5-digit generic drug product number that completely identifies the generic drug product.

Retrieval may be accomplished by one of two basic methods: (1) As an integral component of a computerized medication profile and/or pricing system. (2) Manual selection of pre-punched cards. The file can be easily utilized by individuals who do not have a computerized profile system. They can create a tub file of prepunched index cards and then select the applicable cards upon special request. A prospective review of drug interactions can then be conducted by running a program to search the file in storage. A system similar to this is utilized by the Drug Information Center, Mercy Hospital, Pittsburgh, Pennsylvania (25).

\section{FUTURE APPLICATIONS:}

It is possible to prepare a manual from the drug-drug interaction file. This aspect of the system would be especially useful to individuals without access to electronic data processing facilities. This would serve as a supplementary reference source which would enable the user to rapidly screen a medication profile in lieu of a computerized system. Under certain circumstances a request for 
an immediate computer search is impractical, e.g. servicing a drug information request VIA the telephone or while participating in work and teaching rounds. The major sections, namely, the Source Document, Indexes, and Selected References can be crossindexed, typed and then photoreduced.

Another valuable application of this file is that a drug-induced laboratory test interference file can be used in conjunction with the present system or incorporated into it. Drugs may possess the inherent ability to alter laboratory test values through a variety of pharmacological, physical or chemical mechanisms (27). A drug may affect the normal physiological levels of the particular substance being measured. Through physical or chemical interference, a drug may not only alter a test's value but may prevent its determination by a particular method. The extended biological half-life of drugs as well as intermediate or end products of drug metabolism may often be responsible for unsuspected alteration in laboratory test values. The reporting format and retrieval system is compatible with a program conducted by the Pathology Department of the Rhode Island Hospital, Providence, Rhode Island (28) for reporting possible drug-induced modifications of laboratory test values. In this particular program a computerized cumulative report of all laboratory tests is prepared for every patient who had a test conducted. Immediately following the cumulative report are supplementary 
notes pertaining to drug-induced laboratory interferences for the tests outlined in the report. Although it is ideal to include this information in a cumulative laboratory report there are instances when this may not be practical and it would be preferable to include this information in the medication profile. A prime example would be a situation where a patient obtains health care services from an ambulatory patient care facility. Usually after the initial battery of laboratory tests only a few tests, if any, are conducted for continued surveillance of a particular physiological parameter. In this situation, it would not be economically feasible to run a specific program for laboratory tests.

The file is compatible with existing computerized drug information services. Another advantage of this type of drug-drug interaction file is that its use is not limited to an institutional setting. The system may be incorporated into a computerized drug information service coordinated by a regional drug information network and offered to community practitioners on a subscription basis VIA on-line computer terminals. 


\section{ILLUSTRATION I}

Patient Medication Profile. Example I 


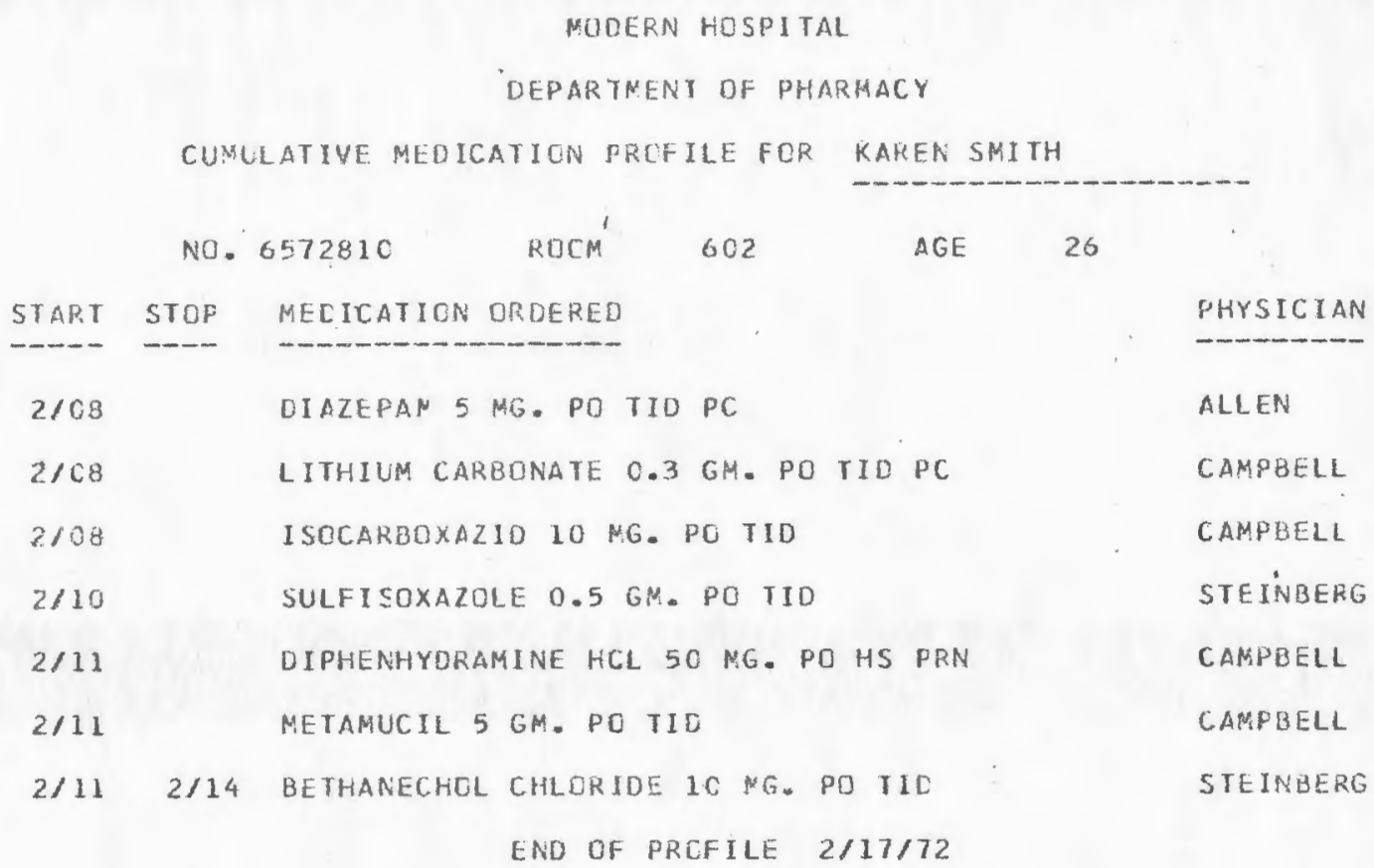


PROBAELE CRUG-DRUG INTERACTIONS FCR KAREN SMITH

ND. 6572810

LITHIUP EXCRETION IS INCREASED BY AMINOPHYLLINE, SCDJUM BICARBCNATE AND LARGE DESES CF SOUIUM CHLURIDE. LCW SODLUM INTAKE MAY PRECIPITATE LITHIUM TCXICITY.

MONOAMINE OXIDASE INHIBITORS PETENTIATE THE PHARMACOLDGICAL EFFECTS OF AMPHEIAMINES, METHYLPHENIOATE (AITALIN), TRICYCLIC AHTIDEPRESSANTS, HYPCGLYCEMICS ANE SYMPATHOMIMETICS SUCH AS EPHEDRINE, METARAMINOL (ARAMINE), PHENYLEPHRINE ANE PHEAYLPROPANULAMINE. CONCOMITANT USE hITH REPERIDINE UR LEVGDOPA INCKEASES INCICENCE DF ACVERSE EFFECTS.

SULFENAMILES MAY POTENTIATE THE HYPOGLYCEMIC RESPÚNSE TO ORAL HYPOGLYCEMICS ANC ELEVATE SERUM LEVELS OF METHCTREXATE. CENCOMITANT USE WITH METHEAAMINE COMPGUNDS FREQUENTLY RESULTS IN CRYSTALLURIA ANE THE FORMAT ION DF A PRECIPITATE.

ANTIHISTAMINES MAY PRODUCE ACDITIVE CNS CEPRESSANT EFFECTS WHEN USED CCNCOMITANILY WITH ETHYL ALCUHOL, BARBITURATES AND PHENGTHIAZINES. THEY MAY POTEIVIIATE THE PHARMACOLOGICAL ACTIVITY OF ANTICHOL INERGICS AND THE ACVERSE EFFECTS GF TRICYCLIC ANTIDEPRESSANTS.

FGR FLRTHER INFORMATION CALL DRUG INFCRMATION CENTER EXT: 1234 
ILLUSTRATION II

Patient Medication Profile. Example II 


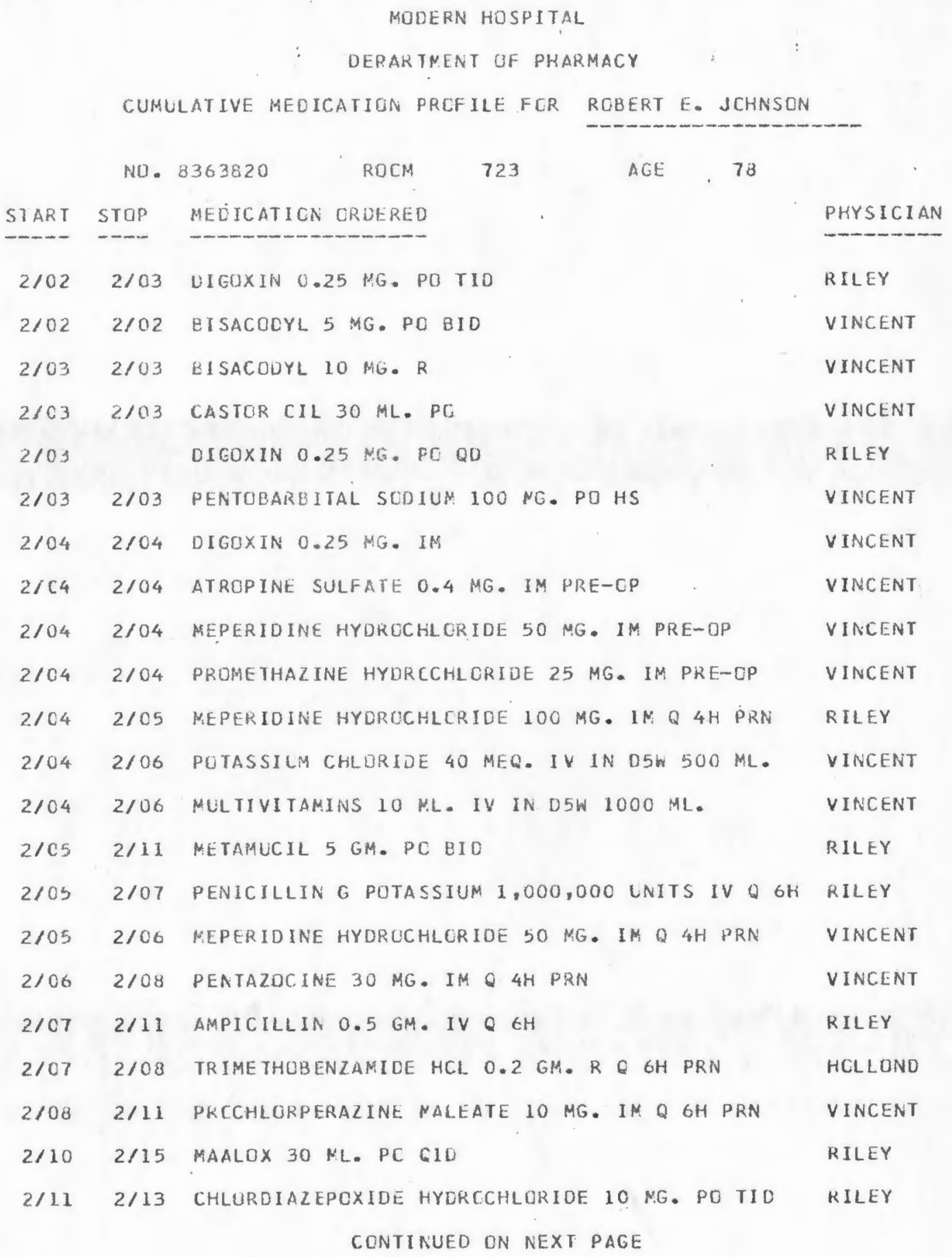




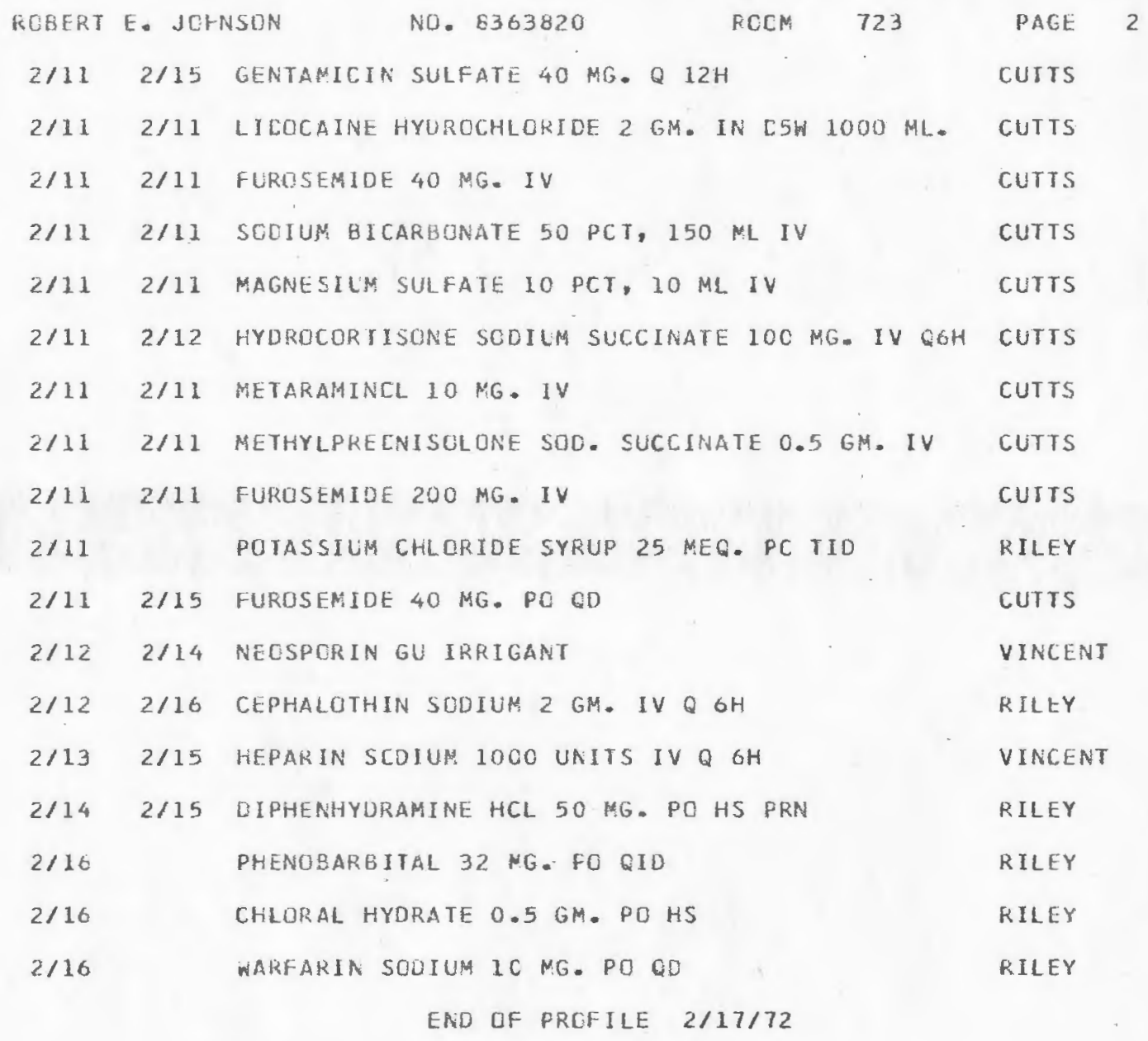


CIGITALIS GLYCOSIDES ARE PHARMACOLOGICALLY POTENTIATED EY PAREMTERAL CALCIUA PREPARATIUNS AND DIUREIICS PRCLUCING POTASSIUM AND MAGNESILA DEFICIENCIES. ANPHOTERICIN B (FUNGIZONE) MAY PRCDUCE HYPOKALENIA PRECIPITATINE DIGITALIS TOXICITY. SYMPATHOHIMETICS NAY INCKEASE INCICENCE UF CARDIAC ARRHYTHISAS.

BAREIURATES- ACDITIVE EFFECTS MAY BE SEEN WITH THE CONCOMITANT USE GF ANTIHISIAMINES, PHENOTHIAZINES ANO CTHER CNS DEPRESSANTS. THEY MAY BE PCTENTIATEE EY PROCAREAZINE (MATULANE). THEY MAY DECREASE THERAPEUTIC EFFECTS CF ORAL ANTICEAGULANTS, TRICYCLIC ANTILEPRESSANTS ANG GRISEOFULVIN. THEY FAY VARIABLY EFFECT SERUM DIPHENYITYDAATCIN LEVELS.

CHLORAL hYDRATE VARIABLY EFFECTS THE ANTICOAGULANT RESPCNSE TO DRAL AAT ICOAGUL ANTS.

DRAL AMTICOAGULANTS ARE POTENTIATED BY ACETAMINOPHEN, ESTRCGENS, ANATULIC STERGIUS, CHLQRAMPHENICQL, CHOLESTYRAMINE (CUEMID), CLGFIBRATE (ATROAID \$1, D-THYRLXINE, PHEAYLBLTAZONE IBUTAZOLIDIN) ANE PHENYRAMIDOL (ANALEXIN). THEY MAY BE POTENTIATEO BY AMINOGLYCCSIDE ANTIBIOTICS, DIPHEAYLHYDANTEIA, INGOMETHACIN, GUINIDIHE ANO SALICYLATES. THEY ARE ANTAGONIZEG BY ETHYL ALCCHOL, BARBITLRATES, ETHCHLCRVYAOL, GHISEGFULVIN AND GLUTEIHIMIDE. THEY ARE VARIABLY AFFECTED BY CHLCRAL HYDRATE.

FOR FLRTHER INFORMATION CALL DRLG INFORMATION CENTER EXT 1234 


\section{CONCLUSIONS}

The design of this computerized drug-drug interaction

file offers several unique features.

1. The program reports important drug-drug interactions with each drug entity the patient is receiving. The system is not limited to the reporting of specific interactions which may occur with the patient's current therapeutic regimen.

2. The reporting format is designed to provide practical information in a concise summary which can be easily understood and utilized in any patient care environment.

3. The printout may be incorporated into a patient's medical record or used strictly as a reference source to screen for drug-drug interactions.

4. The file is compatible with existing computerized medication profiles and record systems as well as computerized drug information services.

5. The use of the drug-drug interaction file is not limited to a hospital or a comprehensive ambulatory patient care facility. The system may be incorporated into a computerized drug information service coordinated by a regional drug information network and offered to community practitioners on a subscription basis. 
6. The various components of the system can be assembled in a manner which would create a cross-idexed manual of human drug-drug interactions. This aspect of the system would be especially useful to individuals without access to electronic data processing facilities.

7. As an added feature the cumulative patient medication profile can be used as a dispensing record for a medication distribution system. 


\section{REFERENCES CITED}

1. Melmon, K.L.: "Preventable drug reactions - causes and cures, "New Eng. J. Med., 248:1361-1368, 1971.

2. Seidl, L.G., et al.: "Studies on the epidemiology of adverse drug reactions. III. Reactions in patients on a general medical service," Bull. Johns Hopkins Hosp., 119:299-315, 1966.

3. Hurwitz, N.: "Admissions to hospital due to drugs," Brit. Med. J., 1:539-540, 1969.

4. Dunphy, T.W.: "The pharmacist's role in the prevention of adverse drug interactions, "Am. J. Hosp. Pharm., 26:366, 1969.

5. Slining, J., et al. : "Development of a drug incompatibility file and its use in patient medication profile reviews, " Am. J. Hosp. Pharm., 27:459, 1970.

6. Hansten, P.D.: "Retrieval and utilization of drug interaction information," Am. J. Hosp. Pharm., 27:469, 1970.

7. Willig, S.H.: "Legal considerations for the pharmacist undertaking new drug consultation responsibilities, " Food Drug Cosmetic Law J., 25:444, 1970.

8. Sjoerdsma, A.: "Catecholamine drug interactions in man," Pharmacol. Rev., 18:673-683, 1966.

9. Hunninghake, D.B., et al. : "Drug interactions with warfarin," Arch. Intern. Med., 121:349-352, 1968. 
10. Field, J.B., et al, : "Potentiation of acetohexamide hypoglycemia by phenylbutazone, "New Eng. J. Med., $277: 889-894,1967$.

11. Blackwell, B. "Hypertensive crisis due to monoamineoxidase inhibitors, " Lancet, 2:849-851, 1963.

12. Lockett, M.F.: "Combining the antidepressant drugs (Letter)," Brit. Med. J., 1:921, 1965.

13. Domino, E.F.: "Barbituate intoxication in a patient treated with MAOI (Letter)," Am. J. Psychiat., 118:941, 1962.

14. Soeldner, J.S.: "Hypoglycemia in tolbutamide-treated diabetes (Letter)," J.Am. Med. Assoc., 193-398, 1965.

15. Boulos, B.M., et al.: "Hazard of simultaneous administration of phenothiazines and piperazine (Letter), "New Eng.J. Med. , 280-1245, 1969.

16. Goodman, L.S. and Gilman, A. (Ed. ): "The Pharmacological Basis of Therapeutics," 4th Ed., The MacMillan Company, New York, 1970, pp. 22-25.

17. Hartshorn, E.A.: "Handbook of Drug Interactions, " Donald E. Francke, Cincinnati, 1970, pp. 7-11.

18. Jawetz, E.: "The use of combinations of antimicrobial drugs," Ann. Rev. Pharmacol, 8:151, 1968.

19. Mirkin, B.L, and Wright, F.: "Drug interactions: Effect of 
methylphenidate on the disposition of diphenylhydantoin in man, "Neurol., 21:1123, 1971.

20. Kupferberg, H.J., et al. : "Effect of methylphenidate on plasma anticonvulsant levels, "Clin. Pharmacol. Therap.: 13:201 (March-April) 1972.

21. Schukit, M., et al.: "Tricyclic antidepressant and monoamine oxidase inhibitors, "Arch. Gen. Psychiat., 24:509, 1971.

22. Winston, F.: "Combined antidepressant therapy," Brit. J. Psychiat., 118:301, 1971 .

23. Cucinell, S.A., et al.: "The effect of chloral hydrate on bishydroxycoumarin metabolism," J.Am. Med. Assoc., 197:366, 1966 .

24. Sellers, E.H. and Koch-Weser, J.: "Potentiation of warfarin-induced hypoprothrombinemia by chloral hydrate, " New Eng. J. Med., 282:827, 1970.

25. Griner, P.F., et al.: "Chloral hydrate and warfarin interaction: Clinical significance", Ann. Intern. Med., $74: 540,1971$

26. Bell, J.E.: "Case presentation: Drug Information Center, Mercy Hospital, "Paper presented at the Institute on Drug Interactions and Clinical Communications, Key Biscayne, Florida, (Oct. 19) 1971. 
27. Elking, Sister Mary and Kabat, H.F.: "Drug induced modifications of laboratory test values," Am. J. Hosp. Pharm., 25:485, 1968. 


\section{APPENDIX I}

\section{Source Document}

-00086 Acetaminophèn

Acetaminophen elevates the anticoagulant response to

oral anticoagulants. $(3,4)$

00124 Acetazolamide

Acetazolamide (Diamox), urinary alkalinizing agent, elavates serum levels of amphetamines (42), tricyclic antidepressants $(33,37)$ and quinidine $(78)$ by enhancing renal reabsorption. It may antagonize the activity of methenamine compounds. (79)

00167 Alcohol, Ethyl

Ethyl alcohol-additive effects may be seen with CNS depressants $(26,54)$ and antihistamines $(26)$. It may antagonize the pharmacological effects of the oral anticoagulants (28) and diphenylhydantoin (104). It may enhance the adverse effects of guanethidine (29), nitroglycerin (27), disulfiram (Antabuse) (30), metronidazole (Flagyl) (31) and tricyclic antidepressants (21). It prolongs the action of insulin. (129)

00205 Allopurinol

Allopurinol potentiates the effects of bishydroxycoumarin (10), and mercaptopurine $(11,58)$. It may increase hepatic 
iron concentration. (140)

00299 Antacids

Antacids containing divalent and trivalent cations decrease oral absorption of tetracyclines. Antacids should not be administered simultaneously with enteric coated products. (6) Sodium polystyrene resin (Kayexalate) binds magnesium and calcium ions found in antacids resulting in systemic alkalosis.

00337 Amantadine

Amantadine (Symmetrel) potentiates the pharmacological effects produced by levodopa. (9)

00434 Aminophyllin

Aminophyllin may impair the therapeutic response to lithium carbonate by increasing the renal excretion of lithium ions. (80) 00515 Aminosalicylic Acid

Aminosalicylic acid plasma levels are elevated by probenecid (Benemid). (81)

00566 Ammonium chloride

Ammonium chloride (urinary acidifier) may decrease renal reabsorption of amphetamines (42) and tricylic antidepressants $(33,37)$.

00604 Amphotericin B

Amphotericin B (Fungizone) may produce hypokalemia 
precipitating digitalis toxicity. (82) It may potentiate

neuromuscular blockade of skeletal muscle relaxants. (82)

00647 Ampicillin

Ampicillin plasma levels are increased by concomitant use

of probenecid (Bènemid). $(43,56)$

00698 Amphetamines

Amphetamines potentiate MAOI (20) and antagonize the effects of guanethidine (40). Phenothiazines may antagonize the central effects of amphetamines (41). Urine acidifying agents decrease renal reabsorption and urinary alkalinizers such as acetazolamide (Diamox), sodium bicarbonate and thiazide diuretics increase reabsorption. (42)

00744 Angiotensin Amide

Angiotensin amide (Hypertensin)-induced antidiuresis and antinatriuresis is reversed by ethacrynic acid (Edecrin) and furosemide (Lasix). (44)

00752 Anabolic Steroids

Anabolic steroids may potentiate the activity of oral anticoagulants (63), phenylbutazone (Butazolidin) and oxyphenbutazone (Tandearil) $(155,156)$ They may decrease insulin requirements in diabetics. (188)

00787 Anticholinergic Drugs

Anticholinergic drugs may potentiate quinidine (83) and the 
secondary pharmacological effects of antihistamines and tricyclic antidepressants. Propranolol (Inderal)-induced - adverse effects are antagonized by anticholinergics. (84) They may produce extrapyramidal symptoms when used simultaneously with methotrimeprazine (Levoprome). (149) 00825 Anticoagulants, Oral

Oral anticoagulants are potentiated by acetaminophen $(3,4)$ estrogens (98), anabolic steroids (63), chloramphenicol (64), cholestyramine (Cuemid) (68), clofibrate (Atromid S) (63), Phenylbutazone (Butazolidin) $(28,39)$ and phenyramidol (Analexin) (72). They may be potentiated by aminoglycoside antibiotics (64), diphenylhydantoin (69), indomethacin (71), quinidine $(28,185)$ and salicylates (13). They are antagonized by ethyl alcohol (28), barbiturates (49), ethchlorvynol (117), griseofulvin $(28,72)$ and glutethimide $(49,70)$. They are variably affected by chloral hydrate $(38,65,66)$. 00876 Antidepressants, Tricyclic

Tricyclic antidepressants may potentiate the adverse effects of MAOI (21) and ethyl alcohol $(21,59)$ and the pharmacological effects of sympathomimetics (36), thyroid preparations (35), antihistamines and anticholinergics. They may antagonize guanethidine $(60,61,62)$. Barbiturates appear to decrease therapeutic activity. (38) They are potentiated by 
methylphenidate. (34) Urine acidifying agents decrease renal reabsorption and urine alkalinizing agents increase reabsorption. $(33,37)$

00884 Antihistamines

Antihistamines may produce additive CNS depressant effects when used concomitantly with ethyl alcohol (26), barbiturates (55) and phenothiazines (157). They may potentiate the pharmacological activity of anticholinergics and the adverse effects of tricyclic antidepressants.

00892 Antihypertensive Agents

Antihypertensive agents may be potentiated by methotrimeprazine (Levoprome) (149), procainamide (Pronestyl) (125, 168) and propranolol (Inderal) $(84,126)$.

00914 Ascorbic Acid

Ascorbic acid (urinary acidifier) may antagonize amphetamines (42) and tricyclic antidepressants $(33,37)$.

00957 Barbiturates

Barbiturates-additive effects may be seen with the concomitant use of antihistamines, phenothiazines and other CNS depressants. (55) They may be potentiated by procarbazine (Matulane) (48). They may decrease therapeutic effects of oral anticoagulants (49), tricyclic antidepressants (38) and griseofulvin (37). 
They may variably effect serum diphenylhydantoin levels. $(45,46)$

. 01058 Bishydroxycoumarin

Bishydroxycoumarin may potentiate the sulfonylureas and increase serum levels of diphenylhydantoin (50). It is potentiated by acetaminophen $(3,4)$, estrogens (98), anabolic steroids (63), chloramphenicol (64), cholestyramine (Cuemid) (68), clofibrate (Atromid S) (63), d-thyroxine (63), phenylbutazone (Butazolidin) $(28,39)$ and phenyramidol (Analexin) (72). It may be potentiated by aminoglycoside antibiotics (64), diphenylhydantoin (69), indomethacin (71) and salicylates (13). It is antagonized by ethyl alcohol (28), barbiturates (49), ethchlorvynol (117), griseofulvin $(28,73)$ and glutethimide $(49,70)$. It is variably affected by chloral hydrate. $(38,65,66)$ 01090 Bisacodyl

Bisacodyl (Dulcolax) tablets should not be taken concomitantly with antacids. (182) 01139 Calcium Preparations (Parenteral)

Calcium ions administered parenterally may pharmacologically potentiate digitalis glycosides. $(74,75)$

01147 Carbenicillin

Carbenicillin (Pyopen, Geopen) plasma levels may be elevated and prolonged by probenecid (Benemid) $(186,187)$ 


\section{Cephalosporins}

Cephalosporins, all-plasma levels are elevated by

probenecid (Benemid) $(43,76)$. Concomitant administration of colistin increases incidence of nephrotoxicity. (96)

01236 Chloral Betaine

Chloral betaine (Beta-Chlor) variably effects the anticoagulant response to oral anticoagulants. $(38,65,66)$ 01317 Chloral Hydrate

Chloral hydrate variably effects the anticoagulant response to oral anticoagulants. $(38,65,66)$

01368 Chloramphenicol

Chloramphenicol may potentiate oral anticoagulants (64), diphenylhydantoin (67) and sulfonylureas (67).

01406 Diuretics

Diuretics producing potassium and magnesium deficiencies may precipitate digitalis toxicity $(94,95)$. Concomitant use with corticosteroids may result in excessive potassium loss (102). Diuretics may antagonize the activity of oral hypoglycemics. (115, 163, 164)

01449 Cholestyramine

Cholestyramine (Cuemid) may elevate the anticoagulant response to oral anticoagulants. (68) It decreases absorption of thyroid preparations by binding thyroxine and triiodo- 
thyronnine. (177)

01481 Clofibrate

Clofibrate (Atromid S) pharmacologically elevates the anticoagulant response to oral anticoagulants (63). It may inhibit platelet adhesiveness. (179)

01546 Colistin

Colistin (Coly-Mycin) enhances neuromuscular blockade of skeletal muscle relaxants. (97) Concomitant administration of parenteral cephalosporins increases incidence of nephrotoxicity. (96) 01589 Corticosteroids

Corticosteroids may be potentiated by estrogens. (99) They may pharmacologically antagonize hypoglycemics $(77,115)$ and decrease salicylate plasma levels (15). Diphenylhydantoin may decrease therapeutic response to corticosteroids. $(100,101)$ Concomitant use with diuretics may result in excessive potassium loss. (102) 01627 Corticotropin

Corticotropin (ACTH) may be potentiated by estrogens (99). It may pharmacologically antagonize hypoglycemics $(77,115)$ and decrease salicylate plasma levels (15). Diphenylhydantoin may decrease response to corticosteroids. $(100,101)$ Concomitant use with diuretics may result in excessive potassium loss. (1.02) 
01678 Dapsone

Dapsone (Avlosulfon) plasma levels are increased by probenecid (Benemid). (103).

01759 Digitalis Glycosides

Digitalis glycosides are pharmacologically potentiated by parenteral calcium preparations $(74,75)$ and diuretics producing potassium and magnesium deficiencies (94, 95). Amphotericin B (Fungizone) may produce hypokalemia precipitating digitalis toxicity. (82) Sympathomimetics may increase incidence of cardiac arrhythmias. (94) 01791 Diphenylhydantoin

Diphenylhydantoin is potentiated by chloramphenicol (67), disulfiram (Antabuse) (105) and isoniazid (106, 107). It may be antagonized by ethyl alcohol (104) and phenyramidol (Analexin) (109). It may potentiate oral anticoagulants (69) and methotrexate (108). It may decrease the therapeutic response to corticosteroids. $(100,101)$ 01848 Dipyridamole

Dipyridamole (Persantine) may potentiate the anticoagulant activity of heparin. $(110,178)$

01880 Disulfiram

Disulfiram (Antabuse) potentiates diphenylhydantoin. (105) Concomitant use with isoniazid (111), ethyl alcohol (30) and 
metronidazole (Flagyl) (112, 113) enhances the incidence of adverse effects.

- 01929 Echothiophate Iodide

Echothiophate iodide (Phospholine iodide) potentiates the pharmacological effects of succinylcholine. (114) 01961 Ephedrine

Ephedrine potentiates hypertensive reactions with MAOI. (23) It antagonizes the adrenergic neuron blockade produced by guanethidine (Ismelin). (40)

02011 Epinephrine

Epinephrine, and to a lesser extent, other adrenergic agents may decrease activity of hypoglycemic agents. (115) 02062 Estrogens

Estrogens pharmacologically elevate the anticoagulant activity of oral anticoagulants. (98) They may potentiate corticosteroid activity. (99)

02100 Ethacrynic Acid

Ethacrynic acid potentiates ototoxicity of aminoglycoside antibiotics. (116) It may produce potassium and magnesium deficiencies precipitating digitalis toxicity. $(94,95)$ Concomitant use with corticosteroids may enhance potassium loss. (102) It may antagonize the activity of oral hypoglycemics. $(163,164)$ 
02143 Ethchlorvynol

Ethchlorvynol (Placidyl) antagonizes the anticoagulant activity of oral anticoagulants. (117)

02194 Folic Acid

Folic acid antagonizes the antineoplastic activity of methotrexate. (118)

02232 Furosemide

Furosemide may produce potassium and magnesium deficiencies precipitating digitalis toxicity. (94, 95) Concomitant use with corticosteroids may enhance potassium loss. (102) It enhances the effects of tubocurarine. (119) It may antagonize the activity of oral hypoglycemics. $(163,164)$ 02275 Gentamicin

Gentamicin in combination with other aminoglycoside antibiotics increases incidence of ototoxicity and nephrotoxicity. (120) Ethacrynic acid potentiates the ototoxicity. (116) It enhances the blockade of skeletal muscle relaxants. (97) 02313 Glutethimide

Glutethimide (Doriden) decreases anticoagulant response to oral anticoagulants. $(49,70)$ 02364 Glyceryl Guaiacolate

Glyceryl guaiacolate may potentiate the anticoagulant 
activity of heparin. $(110,118)$

02402 Griseofulvin

Griseofulvin may decrease the anticoagulant activity of oral anticoagulants. $(28,73)$ It is antagonized by barbiturates which may impair absorption. (37) 02445 Guanethidine

Guanethidine may be potentiated by procainamide (125), propranolol (126) and quinidine (127). It is antagonized by amphetamines (40), tricyclic antidepressants $(60,61,62)$, ephedrine (40) and methylphenidate $(40,122,123)$. It may potentiate phenylephrine (124) and decrease activity of hypoglycemics (88, 89). Ethyl alcohol (29), methotrimeprazine (Levoprome) (121), procarbazine (Matulane) (48) and thiazide diuretics (32) may potentiate orthostatic hypotension. 02496 Heparin

Heparin induced anticoagulant activity may be enhanced by dipyridamole (Persantine) (110) and glyceryl guaiacolate $(110,118)$.

02542 Hypoglycemic Agents, Oral

Oral hypoglycemic agents may be potentiated by chloramphenicol (67). MAOI (22), phenylbutazone (Butazolidin) (2, 165), propranolol (Inderal) (166, 169), bishydroxycoumarin (162), 
phenyramidol (Analexin) (162) and salicylates (17). The hypoglycemic effects are antagonized by corticosteroids (77),

diuretics (115, 163, 164) and guanethidine (Ismelin) (88, 89). 02585 Indomethacin

Indomethacin may pharmacologically elevate the activity of oral anticoagulants. (71) Indomethacin plasma levels may be increased by probenecid (Benemid) (128) and decreased by salicylates (53).

02623 Insulin

Insulin may be pharmacologically antagonized by guanethidine. $(88,89)$ Ethyl alcohol may prolong the action of insulin. (129) Glucocorticoids, thyroid, epinephrine and thiazide diuretics may increase insulin requirements. (115) 02674 Iron Salts

Iron salts should not be used simultaneously with allopurinol (Zyloprim). (140) Antacids may decrease iron absorption. (141) Iron salts may impair the absorption of oral tetracyclines. (183)

02712 Isoniazid

Isoniazid increases plasma levels of diphenylhydantoin. $(106,107)$ It may be antagonized by ethyl alcohol. (130) Concomitant use with disulfiram (Antabuse) (111) and meperidine (131) enhances incidence of adverse effects. 
01716 D-Thyroxine

D-Thyroxine elevates the anticoagulant response to oral anticoagulants. (63)

02755 Isoproterenol

Isoproterenol is pharmacologically antagonized by propranolol (Inderal). (132)

02801 Kanamycin

Kanamycin in combination with other aminoglycoside antibiotics increases incidence of ototoxicity and nephrotoxicity. (120) Concomitant use with ethacrynic acid potentiates the ototoxicity. (116) It potentiates neuromuscular blockade of skeletal muscle relaxants. (97) When administered by the oral route it may increase the activity of oral anticoagulants. (64)

$\underline{02852 \text { Kaolin-Pectin }}$

Kaolin-pectin mixtures inhibit the absorption of orally administered lincomycin (Lincocin), (133)

$\underline{02895 \text { Levodopa }}$

Levodopa may be antagonized by methyldopa (137), pyridoxine (138, 139), reserpine (137) and phenothiazines (85). Concomitant use with MAOI may produce hypertension (136). Additive therapeutic effects may occur with amantadine (Symmetrel). (9) 


\section{Lithium Carbonate}

Lithium excretion is increased by aminophylline (134), - sodium bicarbonate (134) and large doses of sodium chloride (135). Low sodium intake may precipitate lithium toxicity.

02984 Magnesium Salts

Magnesium ions administered parenterally potentiate the neuromuscular blockade of skeletal muscle relaxants. (142) 03034 Meperidine

Meperidine should not be used simultaneously with isoniazid (131) and MAOI (25) - it enhances incidence of adverse effects. It is potentiated by other CNS depressants. 03077 Meprobamate

Meprobamate (Equanil, Miltown) is potentiated by ethyl alcohol. (180, 181)

03115 Mercaptopurine

Mercaptopurine (Purinethol) is potentiated by allopurinol (Zyloprim). (11, 58)

03166 Metaraminol

Metaraminol (Aramine) is pharmacologically potentiated by MAOI. (23)

\section{Methenamine Compounds}

Methenamine compounds exhibit optimum activity in a 
urine ph of 5.5 or lower. Urine acidifying agents are useful adjuncts while urine alkalinizers decrease activity.

- (143) Concomitant use with sulfonamides frequently results in crystalluria and the formation of a precipitate. $(143,144$ 145)

03247 Methoxyflurane

Methotrexate serum levels are elevated by diphenylhydantoin (108), salicylates $(16,146,147)$ and sulfonamides (16, $146,147)$. It may impair the immunological response to smallpox vaccine, resulting in vaccina. (148) 03298 Methotrimeprazine

Methotrimeprazine (Levoprome) potentiates the effects of antihypertensive agents (149), other CNS depressants (149) and skeletal muscle relaxants (149). It will produce extrapyramidal symptoms when used simultaneously with anticholinergics. (149)

03361 Methoxyflurane

Methoxyflurane anesthesia in conjunction with tetracycline therapy increases incidence of nephrotoxic effects. (93) 03344 Methyldopa

Methyldopa may antagonize the therapeutic effects of levodopa (137). Additive hypotensive effects may occur with propranolol (Inderal) (84, 150), procainamide (Pronestyl) 
(125, 168), methotrimeprazine (Levoprome) (149) and thiazide diuretics (184).

03387 Methlyphenidate

Methylphenidate (Ritalin) potentiates tricyclic antidepressants. (34) It may be potentiated by MAOI. $(20,151)$ It antagonizes the pharmacological effects of guanethidine (Ismelin). (40, 122, 123) 03425 Metronidazole

Metronidazole (Flagyl) should not be used simultaneously with disulfiram (Antabuse) $(112,113)$ or ethyl alcohol (31) due to the increased incidence of adverse effects. 03476 Monoamine Oxidase Inhibitors

Monoamine oxidase inhibitors potentiate the pharmacological effects of amphetamines (20), methylphenidate (Ritalin) (20, 151). tricyclic antidepressants (21), hypoglycemics (22) and sympathomimetics such as ephedrine (23), metaraminol (Aramine) (24), phenylephrine and phenylpropanolamine. Concomitant use with meperidine (25) or levodopa (136) increases incidence of adverse effects. 03514 Nafcillin

Nafcillin (Unipen) plasma levels are increased by concomitant use of probenecid (Benemid). (154) 03557 Neomycin

Neomycin in combination with other aminoglycoside antibiotics 
increases incidence of ototoxicity and nephrotoxicity. (120)

Concomitant use with ethacrynic acid potentiates the ototoxicity.

(116) It potentiates neuromuscular blockade of skeletal muscle

relaxants. (97) When administered by the oral route it may in-

crease the activity of oral anticoagulants. (64)

03603 Nitroglycerin

Nitroglycerin may produce hypotension following combined use with ethyl alcohol. (27) Chronic administration of pentaerythritol tetranitrate (Peritrate) may produce a tolerance to nitroglycerin. $(152,153)$

03697 Orphenadrine

Orphenadrine (Norflex) in combination with propoxyphene (Darvon) may produce mental confusion and anxiety. (169, 170) 03735 Oxyphenbutazone

Oxyphenbutazone (Tandearil) elevates the anticoagulant response to oral anticoagulants. $(28,39)$ Oxyphenbutazone plasma levels may be elevated by anabolic steroids. (155, 156) 03743 Penicillin G and Derivatives

Penicillin G and derivatives-plasma levels are elevated by probenecid (Benemid) (8, 43) and salicylates (14). 03751 Pentaerythritol Tetranitrate

Pentaerythritol tetranitrate (Peritrate) therapy may produce a tolerance to nitroglycerin. (152, 153) 
03786 Phenothiazines

Phenothiazines may antagonize levodopa (85) and the central effects of amphetamines (41). Additive effects occur with concomitant use of other CNS depressants (161) and antihistamines (157). Additive cardiac depressant effects are possible with quinidine. (158, 159, 160) Procarbazine (Matulane) may potentiate the CNS depressant effects of phenothiazines. (48)

03824 Phenylbutazone

Phenylbutazone (Butazolidin) elevates the anticoagulant response to oral anticoagulants $(28,39)$ and potentiates the hypoglycemic response to sulfonylureas $(2,165)$. Phenylbutazone plasma levels may be elevated by anabolic steroids. (155, 156) 03867 Phenylephrine

Phenylephrine administered nasally or systemically may be potentiated by guanethidine (Ismelin) (124) and MAOI (23). 03905 Phenylpropanolamine

Phenylpropanolamine may be potentiated by MAOL. (23) 03956 Phenyramidol

Phenyramidol (Analexin) elevates the anticoagulant response to oral anticoagulants (72) and potentiates the activity of diphenylhydantoin (109) and sulfonylureas) (162). 03999 Polymyxin B

Polymyxin B (Aerosporin) enhances neuromuscular blockade of skeletal muscle relaxants. (97) In combination with other 
aminoglycoside antibiotics it increases incidence of ototoxicity and nephrotoxicity. (120)

04230 Probenecid

Probenecid (Benemid) elevates plasma levels of aminosalicylic acid (81), dapsone (Avlosulfon) (103), cephalosporins (43, 77), penicillin $\mathrm{G}$ and derivatives (8, 43) and indomethacin (128). Salicylates inhibit uricosuric activity of probenecid. (19)

04073 Procainamide

Procainamide (Pronestyl) - additive hypotensive effects may occur with concomitant use of antihypertensive agents. $(125,168)$ 04138 Procarbazine

Procarbazine (Matulane) may potentiate the effects of phenothiazines and CNS depressants. (48) It may produce additive hypotensive effects with guanethidine (Ismelin). (48)

\section{Propoxyphene}

Propoxyphene (Darvon) in combination with orphenadrine (Norflex) may produce mental confusion and anxiety. (169, 170) 04219 Propranolol

Propranolol (Inderal) may potentiate oral hypoglycemics (166, $167)$ and antihypertensives $(84,126)$. It antagonizes pharmacological actions of sympathomimetics. (132) Propranolol-induced adverse effects are antagonized by anticholinergics. (84) Additive cardiac depressant effects are possible with quinidine (171, 
172) and phenothiazines $(158,159,160)$

04251 Pyridoxine

- Pyridoxine (Vitamin B6) antagonizes the pharmacological ef-

fects of levodopa. (138, 139)

04308 Quinidine

Quinidine may potentiate guanethidine (127), oral anticoagulants $(28,185)$ and the neuromuscular blockade of muscle relaxants (173). It may be potentiated by anticholinergics (83). Acetazolamide (Diamox), sodium bicarbonate and thiazide diuretics increase renal reabsorption $(5,78,175)$. Additive cardiac depressant effects are possible with propranolol $(171,172)$ and phenothiazines $(158,159$, $160)$.

04340 Reserpine

Reserpine is potentiated by methotrimeprazine (Levoprome). (149) It may antagonize the effects of levodopa. (137) 04383 Salicylates

Salicylates elevate the anticoagulant response to oral anticoagulants (13), increase plasma levels of unbound penicillin G and derivatives (14) and potentiate methotrexate (16) and sulfonylureas (17). Salicylate plasma levels may be decreased by corticosteroids. (15) They may decrease serum levels of indomethacin (Indocin) (53) and inhibit uricosuric activity of sulfinpyrazone (Anturane) (18) and probenecid (Benemid) (19). 
04421 Skeletal Muscle Relaxants

Surgical skeletal muscle relaxants are potentiated by aminoglycoside antibiotics (97), amphotericin B (82), furosemide (119), magnesium ions (142), methotrimeprazine (Levoprome) (149), quinidine (173) and thiazide diuretics (174). Echothiophate iodide potentiates the effects of succinylcholine. (114)

04472 Small Pox Vaccine

Small pox vaccination may result in generalized vaccina with concomitant use of methotrexate. (148) 04510 Sodium Bicarbonate

Sodium bicarbonate elevates serum levels of amphetamines (42), tricyclic antidepressants $(33,37)$ and quinidine $(5,78,175)$ by enhancing renal reabsorption. It may antagonize methenamine compounds (143) and lithium carbonate (134) and decrease oral absorption of tetracyclines (91).

04553 Sodium Chloride

Sodium chloride in large doses may antagonize pharmacological effects of lithium carbonate. (135) Low sodium intake may precipitate lithium toxicity. (135)

04618 Sodium Polystyrene Sulfonate

Sodium polystyrene sulfonate resin (Kayexalate) binds magnesium and calcium ions found in antacids resulting in systemic alkalosis. (176) 


\section{Streptomycin}

Streptomycin in combination with aminoglycoside antibiotics increases incidence of ototoxicity and nephrotoxicity. (120) Ethacrynic acid potentiates the ototoxicity. (116) It potentiates neuromuscular blockade of skeletal muscle relaxants. (97) 04693 Sulfinpyrazone

Sulfinpyrazone (Anturane) induced uricosuria is inhibited by salicylates. (18)

\section{Sulfonamides}

Sulfonamides may potentiate the hypoglycemic response to oral hypoglycemics (1) and elevate serum levels of methotrexate $(16,146,147)$. Concomitant use with methenamine compounds frequently results in crystalluria and the formation of a precipitate. $(143,144,145)$

04782 Tetracyclines

Tetracycline absorption is decreased by antacids (90) containing divalent or trivalent cations, sodium bicarbonate (91) and iron salts (183). It may elevate anticoagulant response to oral anticoagulants (92) and potentiate nephrotoxic effects of methoxyflurane (Penthrane) (93).

04820 Thiazide Diuretics

Thiazide diuretics may precipitate digitalis toxicity $(94,95)$ and antagonize the effects of hypoglycemics $(115,163,164)$. Neuro- 
muscular blockade produced by surgical muscle relaxants may be enhanced. (174) Concomitant use with corticosteroids may result in excessive potassium Ioss. (162) They may produce additive hypotensive effects with guanethidine (Ismelin) (32) and methyldopa (Aldomet) (184).

04863 Thyroid Preparations

Thyroid preparations may potentiate the anticoagulant response to oral anticoagulants. (63) Cholestyramine decreases absorption by binding thyroxine and triiodothyronnine. (177) They may decrease activity of hypoglycemic agents. (115) 


\section{APPENDIX II}

Alphabetical Cross-Index

$\underline{A}$

Acenocoumarol

00825

Benzestrol

02062

Acetaminophen

00086

Acetazolamide

00124

Acetohexamide

02542

Acetophenazine

Maleate

03786

Acetyldigitoxin

01759

Aldactazide

04820

Adiphenine $\mathrm{HC} 1$

00787

Allopurinol

00205

Alphaprodine

00256

Alverine Citrate

00787

Amantadine

00337

Aminophyllin

Aminosalicylic Acid

00434

Amitriptyline $\mathrm{HC} 1$

00515

00876

Ammonium Chloride

00566

Amobarbital

00957

Amphetamine

Sulfate

Amphotericin B

00698

Ampicillin

00604

00647

Agiotensin Amide

00744

Antacids

00299

APC

04383

Aprobarbital

00957

Ascorbic Acid

00914

Aspirin

04383

Atropine Sulfate

00787

Azapetine $\mathrm{HC} 1$

00892

Azo-Gantanol

04731

Azo-Gantrisin

04731

$\underline{B}$

Barbital

00957

Barbital Sodium

00957

Bendroflumethiazide

04820

Benzthiazide

04820

Bethamethasone 01589

Biperiden 00787

Biphetamine-T 00698

Bisacodyl 01090

Bishydroxycoumarin 01058

Butabarbital Sodium 00957

Butalbital

00957

Butape razine Maleate

03786

Butazolidin Alka 03824

$\underline{C}$

Calcium Chloride, Injection

01139

Calcium Gluconate, Injection

01139

Carbenicillin

01147

Carbrital

00957

Carphenazine Maleate

03786

Cholesty ramine

01449

Chloral Betaine

01236

Chloral Hydrate

01317

Chloramphenicol

01368

Chlormerodrin $\quad 01406$

Chlorothiazide $\quad 04820$

Chlorotrianisene 02062

Chlorpromazine

$\mathrm{HC} 1$

03786

Chlorpropamide 02542

Chlortetracycline 04782

Chlorthalidone $\quad 01406$

Clofibrate 01481

Colistin

01546

Combid

03786 


\section{$\underline{D}$}

Corticotropin

Cortisone

C-Quens

Cyclothiazide

Cycrimine $\mathrm{HC} 1$

Cyproheptadine HC1

Dapsone

Darvon Compound

Darvon Compound-65

Decamethonium

Bromide

Demethylchlor tetracycline

Desbutal

Desipramine $\mathrm{HC} 1$

Deslanoside

Dexamethasone

Dexamyl

Dextroamphetamine

Sulfate

Dibutoline Sulfate

Dienestrol

Diethylstilbestrol

Diethylstilbestrol

Diphosphate

Digitalis

Digitalis Glycosides

Digitoxin

Digoxin

Dimethyl Tubocura rine Iodide

Diphenhydramine Hydrochloride

Diphenylhydantoin

Dipyridamole

Disulfiram

Diupres

Doxepin HCL
01627

01589

02062

04820

00787

00884

01678

04170

04383

04170

04383

04421

04782

00698

00957

00876

01759

01589

00698

00957

00698

00787

02062

02062

02062

01759

01759

01759

01759

04421

00884

01791

01848

01880

04340

04820

00876
Doxycycline

04782

D-Thyroxine

01716

Dyazide

04820

$E$

Echothiophate Iodide

Empirin

01929

Ephedrine

04383

01961

Epinephrine

02011

Eskatrol

00167

03786

Estradiol

Estradiol Benzoate

02062

02062

Estradiol Dipropionate

02062

Estrone

02062

Equagesic

03077

04383

Ethacrynic Acid

02100

02143

02062

00167

00825

00752

Ethylestrenol

$\underline{F}$

Ferrous Fumarate

02674

Ferrous Gluconate

02674

Ferrous Sulfate

02674

Fludrocortisone

01589

Fluphenazine Enanthate

03786

Fluphenazine HCL

03786

01589

Fluprednisolone

02194

Folic Acid

02232

$\underline{G}$

Gentamicin

02275

Glutethimide

02313

02364

Glyceryl Guaicolate

02402

Griseofulvin

02445 
$\underline{\mathrm{H}}$

Heparin

02496

00647

Hexafluorenium

Bromide

04421

00957

Hexobarbital

04820

Hydrochlor othiazide

01589

Hydrocortiso ne

04820

Hydroflumethiazide

04340

I

Imipramine

00876

Indometha cin

02585

Insulin

02633

Isocarboxazid

03476

Isoniazid

02712

Isoproterenol

$\underline{\mathrm{K}}$

Kanamycin Sulfate

02801

Kaolin-Pectin

02852

$\underline{\mathrm{L}}$

Lanatoside C

01757

Levodopa

02895

Levothyroxine

04863

L-Hyoscyamine Sulfate

Liothyronine

00787

Liotrix

04863

Lithium Carbonate

04863

02933

M

Magnesium Sulfate, Injection

02984

Meperidine HCL

03034

Mephobarbital

00957

Meprobamate

03077

Meralluride

01406

Mercaptomerin Sodium

01406

Mercaptopurine

03115

Mercurophylline $\quad 01406$

Merethoxylline $\quad 01406$

Metaraminol 03166

Methacycline $\quad 04782$

Methallenestril 02062

Methamphetamine HCL 00698

Methandriol 00752

Methandrostenolone 00752

Methdilazine HCL 00884

Methenamine Hippurate

03204

Methenamine Mandelate

03204

Methenamine Sulfosalicylate $\quad 03204$

Methotrexate 03247

Methotrimeprazine $\quad 03298$

Methoxyflurane $\quad 03361$

Methyclorthiazide $\quad 04820$

Methylatropine Nitrate 00787

Methyldopa

03344

Methylphenidate

03387

Methylprednisolone

01589

Metronidazole

03425

$\underline{N}$

Nafcillin $\quad 03514$

Naldecon 03905

Nandrolone Decanoate 00752

Nandrolone Phenpropionate $\quad 00752$

Neomycin 03557

Nialamide $\quad 03476$

Nitroglycerin 03603

Norethandrolone $\quad 00752$

Norgesic 03697

04383

Nortriptyline HCI $\quad 00876$

$\underline{\mathrm{O}}$

Orphenadrine $\quad 03697$

Ortho-Novum 02062 


\begin{tabular}{|c|c|c|c|}
\hline Ovral & 02062 & Propranolol & 04219 \\
\hline Ovulen & 02062 & Protriptyline HCL & 00876 \\
\hline Oxymetholone & 00752 & Pyridoxine & 04251 \\
\hline Oxyphenbutazone & 03735 & & \\
\hline Oxytetracycline & 04782 & $\underline{Q}$ & \\
\hline \multirow[t]{2}{*}{$\underline{P}$} & & Quabain & 01759 \\
\hline & & Quinethazone & 01406 \\
\hline Paramethasone & 01589 & Quinidine & 04308 \\
\hline Penicillin G & 03743 & & \\
\hline Pentaerythritol & & $\mathrm{R}$ & \\
\hline Tetranitrate & 03751 & & \\
\hline Pentobarbital Sodium & 00957 & Reserpine & 04340 \\
\hline Perphenazine & 03786 & & \\
\hline Phenelzine & 03476 & $\underline{S}$ & \\
\hline Phenformin & 02542 & & \\
\hline Pherindione & 00825 & Salicylamide & 04383 \\
\hline Phenobarbital & 00957 & Scopolamine $\mathrm{HBr}$ & 00787 \\
\hline Phenoxybenzamine & & Secobarbital & 00957 \\
\hline Hydrochloride & 00892 & Ser-Ap-Es & 04340 \\
\hline Phenoxymethyl & & & 04820 \\
\hline Penicillin & 03743 & Small Pox Vaccine & 04472 \\
\hline Phenylbutazone & 03824 & Sodium Bicarbonate & 04510 \\
\hline Phenprocoumon & 00825 & Sodium Chloride & 04553 \\
\hline Phenylephrine & 03867 & Sodium Polystyrene & \\
\hline Phenylpropanolamine & 03905 & Sulfonate Resin & 04618 \\
\hline Phenyramidol & 03956 & Sodium Salicylate & 04383 \\
\hline Piperactazine & 03786 & Stanozolol & 00752 \\
\hline Piperidolate & 00787 & Streptomycin & 04660 \\
\hline Polyestradiol Phosphate & 02062 & Succinylcholine & \\
\hline Polymyxin B & 03999 & Chloride & 04421 \\
\hline Polythiazide & 04820 & Sulfachlorpyridazine & 04731 \\
\hline Prednisone & 01589 & Sulfadiazine & 04731 \\
\hline Prednisolone & 01589 & Sulfadimethoxine & 04731 \\
\hline Probenecid & 04030 & Sulfaethidole & 04731 \\
\hline Procainamide & 04073 & Sulfamerazine & 04731 \\
\hline Procaine Penicillin & 03743 & Sulfameter & 04731 \\
\hline Procarbazine & 04138 & Sulfamethizole & 04731 \\
\hline Prochlorperazine & 03786 & Sulfamethoxazole & 04731 \\
\hline Procyclidine HCL & 00787 & Sulfamethoxypyri- & \\
\hline Promazine & 03786 & dazine & 04731 \\
\hline Promethazine HCL & 03786 & Sulfapyridine & 04731 \\
\hline Promethestrol & & Sulfinpyrazone & 04693 \\
\hline Dipropionate & 02062 & Sulfisoxazole & 04731 \\
\hline Propoxyphene HCL & 04170 & & - \\
\hline Propoxyphene Napsylate & 04170 & & \\
\hline
\end{tabular}


Tetracycline

04782

Thiopropazate Dihydrochloride $\quad 03786$

Thioridazine HCL $\quad 03786$

Thyroglobulin 04863

Thyroid 04863

Tolazoline HCL 00892

Tolbutamide $\quad 02524$

Tolinase 02542

Tranylcypromine $\quad 03476$

Triamcinolone $\quad 01589$

Triamterene 01406

Trichlormethiazide $\quad 04820$

Trifluoperazine HCL $\quad 03786$

Triflupromazine $\quad 03786$

Trihexyphenidyl $\quad 00787$

Trimeprazine 00884

Trimethaphen Camsylate 00892

Tripelennamine 00884

Tubocurarine Chloride 04421

W

Warfarin Sodium $\quad 00825$ 
Message Code Index

Message

Code

00086

00124

00167

00205

00256

00299

00337

00434

00515

00566

00604

00647

00698
Drug

Acetaminophen

Acetazolamide

Ethyl Alcohol

Allopurinol

Alphaprodine

Antacids

Amantadine

Aminophyllin

Aminosalicylic Acid

Ammonium Chloride

Amphotericin B

Ampicillin

Hetacillin

Amphetamine

Sulfate

Biphetamine-T

Desbutal

Dexamyl

Dextroamphetamine Sulfate

Eskatrol

Methamphetamine HCL
Message

Code

00744

00752

00787

00825
Drug

Angiotensin

Ethylestrenol

Methandriol

Methandrostenolone

Nandrolone Decanoate

Nandrolone Phenpropionate Norethandrolone Oxymetholone Stanozolol

Adiphenine HCL Alverine Citrate Atropine Sulfate Biperiden Cycrimine $\mathrm{HCL}$ Dibutoline Sulfate 1-Hyoscyamine Sulfate Methylatropine Nitrate Piperidolate Scopolamine $\mathrm{HBr}$ Trihexyphenidyl Procyclidine HCL,

Acenocoumarol Ethyl Biscoumacetate

Phenindione Phenprocoumon Warfarin Sodium 
Message

Code

00876

00884

00892

00914

00957

01058
Drug

Amitriptyline $\mathrm{HCL}$

Desipramine HCL

Doxepin HCL

Imipramine

Nortriptyline HCL,

Protriptyline HCL

Cyproheptadine Hydro-01147 chloride

Diphenhydramine

01236 Hydrochloride

Methdilazine Hydro- 01317 chloride

Trimeprazine

01368

Tripelennamine

01.406

Azapetine

Hydrochloride

Phenoxybenzamine Hydrochloride

Tolazoline

Hydrochloride

Trimethaphen

Camsylate

Ascorbic Acid

01449

A mobarbital

Aprobarbital

Barbital

Barbital Sodium

Butabarbital Sodium

Butalbital

Carbital

Desbutal

Dexamyl

Hexobarbital

Mephobarbital

Pentobarbital Sodium

Phenobarbital

Secobarbital

Bishydroxycoumarin
Message

Code Drug

Bisacodyl

Calcium Chloride, Injection

Calcium Gluconate, Injection

Carbenicillin

Chloral Betaine

Chloral Hydrate

Chloramphenicol

Chlormerodrin

Chlorthalidone

Meralluride

Merethoxylline

Mercaptomerin

Sodium

Mercurophylline

Quinethazone

Triamterene

Cholestyramine

Clofibrate

Colistin

Betamethasone

Cortisone

Dexamethasone

Fludrocortisone

Fluprednisolone

Hydrocortisone

Methylprednisolone

Paramethasone

Prednisolone

Prednisone

Triamcinolone 
Message

Code

01627

01678

01716

01759

01791

01848

01880

01929

01961

02011

02062
Drug

Corticotropin

Dapsone

D-Thyroxine

Acetyldigitoxin

Deslanoside

Digitalis

Digitalis Glycosides

Digitoxin

Digoxin

Lanatoside $\mathrm{C}$

Quabain

Diphenylhydantoin

Dipyridamole

Disulfiram

Echothiophate Iodide

02402

02445

02496

02542

Benzestrol

C-Quens

Chlorotrianisene

Dienestrol

Diethylstilbestrol

Diethylstilbestrol

Diphosphate

Estradiol

Estradiol Benzoate

Estradiol

Dipropionate

Estrone

Ethinyl Estradiol

Methallenestril

Ortho-Novum

Code

02275

02585

02633

02674
Message

Drug

Ovral

Ovulen

Polyestradiol Phosphate

Promethestrol

Dipropionate

$02100 \quad$ Ethacrynic Acid

$02143 \quad$ Ethchlorvynol

$02194 \quad$ Folic Acid

$02232 \quad$ Furosemide

Gentamicin

Glutethimide

Glyceryl Guaiacolate

Griseofulvin

Guanethidine

Heparin

Acetohexamide

Chlorpropamide

Tolbutamide

Tolinase

Phenformin

Indomethacin

Insulin

Ferrous Fumarate Ferrous Gluconate Ferrous Sulfate

02712 Isoniazid 
Message

Code

02755

02801

02852

02895

02933

02984

03034

03077

03115

03166

03204

03247

03298

03344

03361

03387

03425

03476
Drug

Isop roterenol

Kanamycin

Kaolin-Pectin

Levodopa

Lithium Carbonate

Magnesium Sulfate, Injection

Meperidine

Equagesic

Meprobamate

Mercaptopurine

Metaraminol

Methe namine Hippurate

Methenamine Mandelate

Methenamine

Sulfosalicylate

Methotrexate

Methotrimeprazine

Methyldopa

Methoxyflurane

Methylphenidate

Metronidazole

Isocarboxazid

Nialamide
Message

Code

Drug

Phenelzine

Sulfate

Tranylcypromine

03514

Nafcillin Sodium

03557

03603

03697

03735

03743

03751

03786

Neomycin Sulfate

Nitroglycerin

Norgesic

Orphenadrine

Oxyphenbutazone

Penicillin G

Phenoxymethyl Penicillin

Procaine

Penicillin

Pentaerythritol Tetranitrate

Acetophenazine Maleate

Butaperazine Maleate

Carphenazine Maleate

Chlorpromazine $\mathrm{HCL}$

Combid

Eskatrol

Fluphenazine Enanthate

Fluphenazine HCL

Perphenazine Piperactazine Prochlorperazine $\mathrm{HCL}$

Promazine HCL 
Message

\section{Code}

03824

03867

03905

03956

03999

04030

04073

04138

04170

04219

04251

04308

04340
Drug

Promethazine HCL

Thiopropazate Dihydrochloride

Thioridazine HCL

Trifluoperazine $\mathrm{HCL}$

Triflupromazine

Butazolidin Alka

Phenylbutazone

Phenylephrine

Naldecon

Phenylpropanolamine

Phenyramidol

Polymyxin B

Probenecid

Procainamide

Procarbazine

Darvon Compound

Darvon Compound-65

Propoxyphene HCL

Propoxyphene

Napsylate

Propranolol

Pyridoxine

Quinidine

Diupres

Hydropres

Reserpine

Ser-Ap-Es
Message

Code Drug

04383

APC

Aspirin

Empirin

Equagesic

Norgesic

Salicylamide

Sodium Salicylate

04421

Dimethyl Tubocurarine Iodide

Decamethonium Bromide

Succinylcholine Chloride

Tubocurarine Chloride

04472

04510

04553

04618

04660

04693

04731

Azo-Gantrisin

Azo-Gantanol

Sulfadiazine

Sulfaethidole

Sulfachlorpyridazine

Sulfadimethoxine

Sulfamerazine

Sulfameter

Sulfamethizole 


\author{
Message \\ Code \\ Drug \\ Sulfamethoxazole \\ Sulfamethoxypy- \\ ridazine \\ Sulfapyridine \\ Sulfisoxazole \\ 04782 \\ Chlortetracycline \\ Demethylchlortet- \\ racycline \\ Doxycycline \\ Methacycline \\ Oxytetracycline \\ Tetracycline \\ 04820 \\ Aldactazide \\ Bendroflumethiazide \\ Benzthiazide \\ Chlorothiazide \\ Cyclothiazide \\ Diupres \\ Dyazide \\ Hydrochlorothiazide \\ Hydroflumethiazide \\ Hydropres \\ Methyclorthiazide \\ Polythiazide \\ Ser-Ap-Es \\ Trichlormethiazide \\ 04863 \\ Liothyronine \\ Liotrix \\ Levothyroxine \\ Thyroid \\ Thyroglobulin
}




\section{APPENDIX IV}

\section{Selected References}

1. Garb, S.: "Clinical Guide to Undesirable Drug Interactions and Interferences," Springer Company, New York, 1971, p. 18.

2. Field, J.B., et al: "Potentiation of acetohexamide hypoglycemia by phenylbutazone," New Eng. J. Med., 277:889, 1967.

3. Antlitz, A.M., et al: "Potentiation of oral anticoagulant therapy by acetaminophen, "Curr. Ther. Res., 10:501, 1968.

4. Antlitz, A.M. and Awalt, L.F.: "A double blind study of acetaminophen used in conjunction with oral anticoagulant therapy," Curr. Ther. Res., 11:360, 1969.

5. Gerhardt, R.E., et al: "Quinidine excretion in aciduria and alkaluria, "Ann. Int. Med., 71:927, 1969.

6. Goodman, L.S. and Gilman, A.: "The Pharmacological Basis of Therapeutics, " 4th Ed., Macmillan Co., New York, 1970, pp. $1253-1268$.

7. Stuart, D. M.: "Drug metabolism Part II. Drug interactions," Pharmindex, 1968, pp. 1-14.

8. Goodman, L.S. and Gilman, A.: Op. cit., p. 889.

9. Godwin-Austin, R.B.: "Combined treatment of parkinsonism with 1-dopa and amantadine," Lancet, 2:383, 1970.

10. Vesell, E.S.: "Impairment of drug metabolism in man by 
allopurinol and nortriptyline, "New Eng. J. Med., 283: 1484, 1970.

11. Mercaptopurine, Product Information, Burroughs Wellcome, 1971.

12. Sawyer, N.J., et al.: 'A Documented, Cross-Indexed Manual to Human Drug Interactions, "2nd Ed., University of Alabama, Birmingham, Alabama, 1971, p. 9.

13. Hansten, P.D.: "Drug Interactions, "Lea and Febriger, Philadelphia, 1971, p. 28.

14. Garb, S.: Op. cit., p. 54.

15. Klinenberg, M.F.: "Effect of corticosteroids on blood salicylate concentration," J.Am. Med.Assoc., 194: 601, 1965.

16. Methotrexate, Product Information, Lederle Laboratories, 1970.

17. Hansten, P.D.: Op. cit., p. 65.

18. Yu, T.F., et al., "Mutual suppression of the uricosuric effects of sulfinpyrazone and salicylates: A study in interactions between drugs, " J. Clin. Invest., 42:1330, 1963.

19. Robinson, W.D. "Current status of the treatment of gout," J. Am. Med. Assoc., 164: 1670, 1957.

20. Krisko, I., et al., "Severe hyperpyrexia due to tranylcypromine-amphetamine toxicity, "Ann. Int. Med., 70: 559, 1969. 
21. Lockett, M. F. and Milner, G.: "Combining the antidepressant drugs, "Brit. Med. J., 1: 921, 1965.

22. Cooper, A.J. and Ashcroft, G.: "Modification of insulin and sulfonylurea hypoglycemia by monoamine-oxidase inhibitor drugs, " Diabetes, 16:272, 1967.

23. Elis, J., et al.: "Modification by monoamine oxidase inhibitors of the effect of some sympathomimetics on blood pressure," Brit. Med. J., 2: 75, 1967.

24. Hansten, P.D.: "Op. cit., p. 170-171.

25. Sjoqvist, F.: "Psychotopic drugs. Interaction between monoamine oxidase inhibitors and other substances, "Proc. Roy. Soc. Med., 58:967, 1965.

26. Parker, W. J.: "Clinically significant alcohol drug interactions," J.Amer. Pharm. Assoc., 10:664, 1970.

27. Shafer, N.: "Hypotension due to nitroglycerin combined with alcohol," New Eng. J. Med., 273: 1169, 1965.

28. Udall, J.A.: "Drug interference with warfarin therapy (abst.)," Amer. J. Cardiol., 23: 143, 1969.

29. Goodman, L.S. and Gilman, A.: Op. cit., pp. 135-145.

30. Goodman, L.S. and Gilman, A.: Op. cit., pp. 146-148.

31. Penick, S.B., et al.: "Metronidazole in the treatment of alcoholism," Amer. J. Psychiat., 125: 1063, 1969.

32. Shelburne, P.F., et al.: "Guanethidine in combination with 
with hydralazine and with hydrochlorothiazide in hypertension," Amer. J. Med. Sci., 247: 307, 1964.

33. Sjoqvist, F. "The $\mathrm{pH}$-dependent excretion of monomethylated tricyclic antidepressants in dogs and man, "Clin. Pharmacol. Therap. 10:826, 1969 .

34. "The Medical Letter on Drugs and Therapeutics, "Drug and Therapeutic Inc., New York, 11: 47, 1960.

35. Prange, A.J., et al.: "Enhancement of imipramine antidepressant activity by thyroid hormone," Amer. J. Psychiat. , $126: 457,1969$

36. Stone, C.A., et al.: "Antagonism of certain effects of catecholamine-depleting agents by antidepressant and related drugs," J. Pharmacol. Exp. Ther., 144: 196, 1964.

37. Milne, M.D.: "Influence of acid-base balance on efficacy and toxicity of drugs, "Proc. Roy. Soc. Med., 58: 961, 1965.

38. Hansten, P.D.: Op. cit., p. 183.

39. Robinson, D.S. and Sylvester, D.: "Interaction of commonly prescribed drugs and warfarin, "Ann. Int. Med., 72: 853, 1970.

40. Gualati, O. D., et al.: "Antagonism of adrenergic neuron blockade in hypertensive subjects, " Clin. Pharmacol. Ther., 7: 510,1966

41. Espelin, D.E. and Done, A.K.: "Amphetamine poisoning: 
Effectiveness of chlorpromazine, "New Eng. J. Med., 278: 1361,1968 .

42. Rowland, M. "Amphetamine blood and urine levels in man," J. Pharm. Sci., 58:508, 1969.

43. Gilbaldi, M. and Schwartz, M.A. : "Apparent effect of probenecid on the distribution of penicillins in man, "Clin. Pharmacol. Therap., 9:345, 1968.

44. Rado, J.P.: "Studies on the sites of action of ethacrynic acid and furosemide during angiotensin infusion, "J. Clin. Pharmacol. J. New Drugs, 10:375, 1970.

45. Cucinell, S.A., et al.: "Drug interactions in man. Lowering effect of phenobarbital on plasma levels of bishydroxycoumarin and diphenylhydantoin, "Clin. Pharmacol. Ther., 6:420, 1965.

46. Kutt, H., et al.: "The effect of phenobarbital upon diphenylhydantoin metabolism in man (abst.), "Neurology, 15: 274, 1965.

47. Busfield, D. et al.: "An effect of phenobarbitone on bloodlevels of griseofulvin in man, "Lancet, 2: 1042, 1963.

48. Procarbazine, Product Information, Roche Laboratoires, 1969.

49. MacDonald, M.G., et al.: "The effects of phenobarbital, chloral betaine, and glutethimide administration on warfarin plasma levels and hypoprothrombinemic responses in man, " 
Clin. Pharmacol. Ther., 10: 80, 1969.

50. Hansen, J.M., et al.: "Dicumarol-induced diphenylhydantoin," Lancet, 2: 265, 1966.

51. Kristensen, M. and Hansen, J.M.: "Potentiation of the tolbutamide effect of Dicumarol," Diabetes, 16:211, 1967.

52. Kristensen, M. and Hansen, J. M.: "Accumulation of chlorpropamide caused by Dicumarol," Acta. Med. Scand., 183, 1968.

53. Jeremy, R. and Towson, J.: "Interaction between aspirin and indomethacin in the treatment of rheumatoid arthritis, " Med. J. Australia., 2: 127, 1970.

54. Zirkle, G.A., et al.: "Effects of chlorpromazine and alcohol on coordination and judgement," J.Am. Med. Assoc., 171: $1496,1959$.

55. Goodman, L.S. and Gilman, A.: Op. cit., pp. 98-120.

56. Gundersen, T., et al.: "Treatment of gonorrhoea by one oral dose of ampicillin and probenecid combined, "Brit. J. Veneral. Dis., 45:235, 1969.

57. Blackwell, B., et al.: "Hypertensive interactions between monoamine oxidase inhibitors and foodstuffs, "Brit. J. Psychiat., 113: 349, 1967.

58. Goodman, L.S. and Gilman, A.: Op. cit., pp. 1371-1375. 59. Landauer, A.A., et al.: "Alcohol and amitriptyline effects 
on skills related to driving behavior, "Science, 163: 1467, 1969.

60. Mitchell, J.R., et al.: "Antagonism of the antihypertensive action of guanethidine sulfate by desipramine hydrochloride, " J. Am. Med. Assoc., 202: 973, 1967.

61. Leishman, A.W., et al.; "Antagonism of guanethidine by imipramine, "Lancet, 1: 112, 1963.

62. Meyer, J.F., et al.: "Insidious and prolonged antagonism of guanethidine by amitriptyline," J.Am. Med. Assoc., 213: $1487,1970$.

63. Schrogie, J.J. and Solomon, H. M.: "The anticoagulant response to bishydroxycoumarin. II. The effect of d-thyroxine, clofibrate, and norethandrolone, "Clin. Pharmacol. Ther., $8: 70,1967$.

64. Kippel, A.P. and Pitsinger, B.: "Hypothrombinemia secondary to antibiotic therapy and manifested by massive gastrointestinal hemorrage," Arch. Surg., 96: 266, 1968.

65. Sellers, E.M. and Koch-Weser, J.: "Displacement from albumin and potentiation of warfarin by five acidic drugs," Clin. Res., 18, 344, 1970.

66. Sellers, E. and Koch-Weser, J.: "Potentiation of warfarininduced hypoprothrombinemia by chloral hydrate, "New Eng. J. Med., 283: 827, 1970. 
67. Christensen, L.K. and Skovsted, L.: "Inhibition of drug metabolism by chloramphenicol, "Lancet, 2: 1397, 1969.

68. Gross, L. and Brotman, M.: "Hypoprothrombinemia and hemorrage associated with cholestyramine therapy, "Ann. Int. Med., 72: 95, 1970.

69. Hansten, P.D.: Op. cit., p. 21.

70. Hunninghake, D.B. and Azarnoff, D.L.: "Drug interactions with warfarin," Arch. Int. Med., 121: 349, 1968.

71. Hansten, P.D.: Op. cit., p. 23.

72. Carter, S.A. : "Potentiation of the effect of orally administered anticoagulants by phenyramidol HCl, "New Eng. J. Med., 273: $423,1965$.

73. Cullen, S.I. and Catalano, P.M.: "Griseofulvin-warfarin antagonism," J. Am. Med. Assoc., 199: 582, 1967.

74. Smith, J.W. (Ed. ): "Manual of Medical Therapeutics," 19th Ed., Little, Brown and Co., Boston, 1969, p. 46.

75. Goodman, L.S. and Gilman, A.: Op. cit., pp. 677-708.

76. Applestein, J.M., et al.: "In vitro antimicrobial activity and human pharmacology of cephaloglycin, "Appl. Microbiol., 16: 1006, 1968.

77. Alavi, I. A. and Pillay, V.K.: "Steroid-induced diabetic ketoacidosis (Abst.), "Ann. Int. Med., 72: 787, '1970.

78. Knouss, R.F., et al.: "Variation in quinidine excretion with 
changing urine pH (abst.)," Ann. Int. Med., 68: 1157, 1968.

79. Methenamine Mandelate, Product Information, Warner-Chilcott Laboratories, 1968.

80. Thomsen, K. and Schou, M.: "Renal lithium excretion in man," Amer. J. Physiol., 215: 823, 1968.

81. Hansten, P.D.: Op. cit., p. 96.

82. Miller, R.P. and Bates, J.H.: "Amphotericin B toxicity. A follow-up report of 53 patients, "Ann. Int. Med., 71: 1089, 1969.

83. Goodman, L.S. and Gilman, A.: Op. cit., pp. 711-719.

84. Propranolol, Product Information, Ayerst Laboratories, 1969.

85. Cotzias, G,C., et al.: "L-dopa in Parkinson's syndrome," New Eng. J. Med., 281: 272, 1969.

86. Giles, T.D. and Modlin, R.K.: "Death associated with ventricular arrhythmia and thioridazine HCl, "J. Am. Med. Assoc., 205: 108, 1968.

87. Spenney, J.G., et al.: "Hyperglycemic, hyperosmolar, nonketoacidotic diabetes: A complication of steroid and immunosuppressive therapy, "Diabetes, 18: 107, 1969.

88. Gupta, K. K. and Lillicrap, C.A.: "Guanethidine and diabetes (Letter), "Brit. Med. J., 2: 697, 1968.

89. Gupta, K. K.: "Guanethidine and glucose tolerance in diabetes (Letter)," Brit. Med. J., 21: 679, 1968. 
90. Kunin, C.M. and Finland, M.: "Clinical pharmacology of the tetracycline antibiotics," Clin. Pharmacol. Therap., 2: 51, 1961.

91. Hansten, P.D.: Op. cit., p. 134.

92. Searcy, R.L., et al.: "Blood clotting a nomalies associated with intensive tetracycline therapy, "Clin. Res., 12: 230, 1964.

93. Kuzucu, E.Y.: "Methoxyflurane, tetracycline, and renal failure," J. Am. Med. Assoc., 211: 1162, 1970.

94. Smith, J.W. (Ed.): Op. cit., pp. 96-105.

95. Seller, R.H., et al.: "Digitalis toxicity and hypomagnesemia," Amer. Heart. J., 79: 57, 1970.

96. Koch-Weser, J., et al.: "Adverse effects of sodium colistimethate. Manifestations and specific reaction rates during 317 courses of therapy, "Ann. Int. Med., 72: 857, 1970.

97. Pittinger, C.B., et al.: "Antibiotic-induced paralysis," Anesth. Analg., 49: 487, 1970.

98. Schrogie, J.J., et al.: "Effect of oral contraceptives on vitamin $\mathrm{K}$-dependent clotting activity, "Clin. Pharmacol. Ther., $8: 670,1967$.

99. Spangler, A.S., et al.: "Enhancement of the antiinflammatory action of hydrocortisone by estrogen, " J. Clin. Endocr., 29: 650,1969 .

100. Werk, E.F., et al.: "Interference in the effect of dexamethasone 
by diphenylhydantoin, "New Eng. J. Med., 281: 32, 1969.

101. Jubiz, W., et al.: "Effect of diphenylhydantoin on the metabolism of dexamethasone. Mechanism of the abnormal dexamethasone suppression in humans," New Eng. J. Med., 283: 11, 1970 .

102. Thorn, G.W.: "Clinical considerations in the use of corticosteroids, "New Eng. J. Med., 274: 775, 1966.

103. Goodwin, C.S. and Sparell, G.: "Inhibition of dapsone excretion by probenecid, "Lancet, 2: 884, 1969.

104. Kater, R. M., et al.: "Increased rate of clearance of drugs from the circulation of alcoholics, "Amer. J. Med. Sci., 258: 35,1969 .

105. Olesen, O.V.: "The influence of disulfiram and calcium carbimide on the serum diphenylhydantoin, "Arch. Neurol., 16: $642,1967$.

106. Kutt, H., et al.: "Diphenylhydantoin intoxication. A complication of isoniazid therapy, "Amer. Rev. Resp. Dis., 101: $337,1970$.

107. Murray, F.J.: "Outbreak of unexpected reactions among epileptics taking isoniazid," Amer. Rev. Resp. Dis., 86: 729, 1962.

108. Hartshorn, E.A.: "Drug interactions: Antineoplastics," Drug Intell. and Clin. Pharm., 3: 196, 1969. 
109. Solomon, H.M. and Schrogie, J.J.: "The effect of phenyramidol on the metabolism of diphenylhydantoin, " Clin. Pharmacol. Ther., 8:554, 1967.

110. Berger, S.: "Platelet function: A review. Part II. Abnormal function," Canad. Med. Assoc. J., 102: 1379, 1970.

111. Whittington, H.G. and Grey, L.: "Possible interaction between disulfiram and isoniazid," Amer. J. Psychiat., 125: $1725,1969$.

112. Rothstein, E. and Clancy, D.D.: "Toxicity of disulfiram combined with metronidazole," New Eng. J. Med., 280:1006, 1969.

113. Goodhue, W.W.: "Disulfiram-metronidazole toxicity, "New Eng. J. Med, , 280:1482, 1969.

1.14. Cavallaro, R.J., et al.: "Effect of ecothiophate therapy on metabolism of succinylcholine in man, " Anesth. Analg., 47: $570,1968$.

115. Smith, J.W. (Ed.): Op. cit., p. 317.

116. Mathog, R.H. and Klein, W. J.: "Ototoxicity of ethacrynic acid and aminoglycoside antibiotics in uremia," New Eng. J. Med., 280: 1223, 1969.

117. Johansson, S.: "Apparent resistance to oral anticoagulant therapy and influence of hypnotics on some coagulation factors," Acta. Med. Scand., 184: 297, 1968. 
118. Eastham, R.D. and Griffiths, E.P.: "Reduction of platelet adhesiveness and prolongation of coagulation time of activated plasma by glyceryl guaiacolate, "Lancet, 1: 795, 1965.

119. Furosemide, Product Information, Hoechst Pharmaceutical Co., 1969.

120. Garamycin, Product Information, Schering Corporation, 1969.

121. Methotrimeprazine, Product Information, Lederle Laboratories, 1966

122. Desmankar, B.S. and Lewis, J.A.: "Ventricular tachycardia associated with the administration of methylphenidate during guanethidine the rapy, "Canad. Med. Assoc. J., 97: 1166, 1967.

123. Methylphenidate, Product Information, CIBA Pharmaceutical Co., 1970.

124. Sneddon, J.M. and Turner, P. "The interactions of local guanethidine and sympathomimetic amines in the human eye," Arch. Ophthal., 81:622, 1969.

125. Goodman, I.S. and Gilman, A.: Op. cit., pp. 719-722.

126. Waal, H. J.: "Hypotensive action of propranolol, "Clin. Pharmacol. Ther., 7:588, 1966.

127. Goodman, L.S. and Gilman, A.: Op. cit., 711-719.

128. Skeith, M.D., et al. : "The renal excretion of indomethacin and its inhibition by probenecid," Clin. Pharmacol. Ther., 
99: 89, 1968.

129. Arky, R.A.: "Irreversible hypoglycemia. A complication of alcohol and insulin," J. Am. Med. Assoc., 206:575, 1968.

130. Meyler, L. (Ed.): "Side Effects of Drugs," 4th Ed., Exerpta Medica Foundation, Amsterdam, 1964, pp. 137-141.

131. Meperidine $\mathrm{HCl}$, Product Information, Winthrop Laboratories, 1969

132. Michaelis, E. and Rosen, A.: "Depression of isoprenalineinduced idioventricular rhythm in man by betaadrenergic receptor blocking agents," Acta. Med. Scand., 183:401, 1968.

133. McCall, C.E., et al.: "Lincomycin: activity in vitro and absorption and excretion in normal young men, "Amer. J. Med. Sci., 254:144, 1967.

134. Thomsen, K. and Schou, M. : "Renal lithium excretion in man, "Amer. J. Physiol., 215:823, 1968.

135. Platman, S.R. and Fieve, R.R.: "Lithium retention and excretion. The effect of sodium and fluid intake, "Arch. Gen. Psychiat., 20:285, 1969.

136. Friend, D.G., et al.: "The action of 1-dihydroxyphenylalanine in patients receiving nialamide, "Clin. Pharmacol. Ther. , $6: 362,1965$

137. Cotzias, G.C., et al.: "L-dopa in Parkinson's syndrome (Letter)," New Eng. J. Med., 281:272, 1969. 
138. Duvoisin, R.C., et al.: "Pyridoxine reversal of 1-dopa effects in parkinsonism, "Trans. Amer. Neurol. Assoc., $94: 81,1969$

139. Cotzias, G.C.: "Metabolism modification of some neurologic disorders," J.Am. Med. Assoc., 210: 1255, 1969.

140. Allopurinol, Product Information, Burroughs Wellcome and Co., 1970.

141. Fill, G.J. and Davis, A.E.: "Inhibition of iron absorption by magnesium trisilicate," Med. J. Aust., 2: 95, 1969.

142. Ghoneim, M. M. and Long, J.P.: "The interaction between magnesium and other neuromuscular blocking agents, " Anesthesiology, 32: 23, 1970 .

143. Methenamine Mandelate, Product Information, Warner-Chilcott Laboratories, 1968.

144. Meyers, F.H., et al.: "Review of Medical Pharmacology," 2nd, Ed., Lange Medical Publications, Los Altos, California, 1970, pp. 494-497.

145. Lipton, J.H.: "Sulfamethizole and methenamine incompatibility, "New Eng. J. Med., 2: 92, 1963.

146. Dixon, R.L., et al.: "Plasma protein binding of methotreate and its displacement by various drugs," Fed. Proc., 24: 452, 1965.

147. Liegler, D.G., et al.: "The effect of organic acids on renal 
clearance of methotrexate in man, "Clin. Pharmacol. Ther., $10: 849,1969$.

148. Allison, J.: "Methotrexate and smallpox vaccination (Letter)," Lancet, 2: 1250, 1968 .

149. Methotrimeprazine, Product Information, Lederle Laboratories, 1966.

150. Waal, H.J. "Hypotensive action of propranolol, " Clin. Pharmacol. Ther., 7: 588, 1966.

151. Methylphenidate, Product Information, CIBA Pharmaceuticals, 1970.

152. Meyers, F.H., et al.: Op. cit., pp. 105-109.

153. Schelling, J.L. and Lasagna, L.: "A study of cross-tolerance to circulating effects of organic nitrates, "Clin. Pharmacol. Ther., 8: 256, 1967.

154. Gibaldi, M. and Schwartz, M.A.: "Apparent effect of probenecid on the distribution of penicillins in man, "Clin. Pharmacol. Ther., 9: 345, 1968.

155. Hvidberg, E.F., et al.: "Studies of the interaction of phenylbutazone, oxyphenbutazone and methandrostenolone in man, " Proc. Soc. Exp. Biol. Med., 129: 438, 1968.

156. Weiner, M., et al. : "Effect of steroids on disposition of oxyphenbutazone in man, "Proc. Soc. Exp. Biol. Med., 124: 1170,1967 . 
157. Goodman, L.S. and Gilman, A.: Op. cit., pp. 98-120.

158. Fletcher, G.F., et al.: "Cardiotoxic effects of Mellaril: Conduction disturbances and supraventricular arrhythmias, " Amer. Heart J., 78: 135, 1969.

159. Goodman, L.S. and Gilman, A. : Op. cit., pp. 155-169.

160. Giles, T.D. and Modlin, R.K.: "Death associated with ventricular arrhythmia and thioridazine hydrochloride," J. Am. Med. Assoc., 205: 108, 1968.

161. Sadove, M.S., et al.: "The potentiating action of chlorpromazine," Anesth. Analg., 35: 165-181, 1956.

162. Solomon, H. M. and Schrogie, J. J.: "Effect of phenyramidol and bishydroxycoumarin on the metabolism of tolbutamide in human subjects, " Metabolism, 16:1029, 1967.

163. Malinis, J.MI.: "Diuretics in diabetes mellitus (Letter)," Practitioner, 201:529, 1968.

164. Tranquada, R.E.: "Diuretics for diabetic patient taking an oral hypoglycemic agent (Letter), " J. Am. Med. Assoc., $206: 1580,1968$.

165. Slade, I.H. and Iosefa, R.N. : "Fatal hypoglycemic coma from the use of tolbutamide in elderly patients: report of two cases," J. Am. Geriat. Soc., 15: 948, 1967.

166. Kotler, M.N., et al.: "Hypoglycemia precipitated by propranolol, "Lancet, 2:1389, 1966. 
167. Abramson, E.A. and Arky, R.A.: "Role of beta-adrenergic receptors in counterregulation to insulin-induced hypoglycemia, " Diabetes, 17: 141, 1968.

168. Smith, J.W.: Op. cit., pp. 119-122.

169. Orphenadrine, Product Information, Riker Laboratories, 1969. 170. Propoxyphene, Product Information, Eli Lilly and Co., 1969.

171. Dreifus, L.S., et al.: "Propranolol and qunidine in the management of ventricular tachycardia," J. Am. Med. Assoc., 204: $736,1968$.

172. Stern, S.: "Synergistic action of propranolol with quinidine," Amer. Heart J., 72: 569, 1966.

173. Schmidt, J. L., et al.: "The effect of quinidine on the action of muscle relaxants," J. Am. Med.Assoc., 183: 669, 1963.

174. Hydrochlorothiazide, Product Information, CIBA Pharmaceutical Co., 1969.

175. Milne, M. D.: "Influence of acid-base balance on the efficacy and toxicity of drugs," Proc. Roy. Soc. Med., 58: 961, 1965.

176. Schroeder, E.T.: "Alkalosis resulting from combined administration of a non-systemic antacid and a cation-exchange resin, "Gastroenterology, 56: 868, 1969.

177. Northcutt, R.C., et al.: "The influence of cholestyramine on thyroxin absorption, "J. Am. Med. Assoc., 208: 1857, 1969.

178. Azarnoff, D. L. and Hurwitz, A.: "Drug interactions, " 
Pharmacol. Physicians, 4: 1, 1970.

179. Albert, M. and Stansell, M.J.: "Vascular symptomatic relief during administration of clofibrate, " Metabolism, 18: 635, 1969.

180. Goldberg, L.: "Behavioral and physiological effects of alcohol on man, "Psychosom. Med., 28: 570-595, 1966.

181. Zirkle, G.A.: "Meprobamate and small amounts of alcohol. Effects on human ability, coordination, and judgement, " J. Am. Med. Assoc., 173: 1823-1825, 1960.

182. Bisacody1, Product Information, Geigy Pharmaceuticals, 1971.

183. Neuvonen, P.J., et al.: "Interference of iron with the absorption of tetracycline in $\operatorname{man}_{3} "$ Brit. Med. J., 4: 509, 1970.

184. Osal, A., et al.: "The United States Dispensatory and Physicians' Pharmacology, "26th Ed., Lippincott, Philadelphia, 1967 , p. 29.

185. Koch-Weser, J. "Quinidine-induced hypoprothrombinemic hemorrage in patients on chronic warfarin therapy, "Ann. Int. Med., 68: 511, 1968.

186. "The Medical Letter on Drugs and Therapeutics", Drug and Therapeutic Information Inc., New York, 12: 41, 1970.

187. Carbenicillin, Product Information, J.B. Roerig Division, 1971.

188. Landon, J., et al.: "The effect of a nabolic steroids on blood sugar and plasma levels in man, "Metabolism, 12: 924, 1963. 
APPENDIX V

Drug-Drug Interaction Printout 
ACETAMINOPHEN ELEVATES THE ANIICCAGULANT RESPONSE TO ORAL ANTICOAGULANIS.

ACETAZOLAMILE (OIAMOX), URINARY ALKALINILING AGENT, ELEVATES SERUN LEVELS OF AMFHETAMINES, TRICYCLIC ANTIDEPRESSANTS ANO QUINIDINE BY ENHANCING REAAL REABSORPTION. IT MAY ANTAGUNIZE THE ACTIVITY CF METHENANINE COMPCUNCS.

ETHYL ALCCHOL-ADDITIVE EFFECTS MAY BE SEEN ITH CNS DEPRESSANTS AND ANTIHISTAMINES. IT MAY ANTAGONIZE THE PHARMACOLCGICAL EFFECTS OF THE ORAL ANTICOAGULANTS AND LIPHENYLHYDAKTCIN. IT MAY ENHANCE THE ACVERSE EFFECTS UF ELANETHIOINE, NITROELYCERIN, DISULFIRAM (ANTAEUSE), METRONIDAZOLE (FLAGYL) ANO TRICYCLIC ANTIDEPRESSANTS. IT PROLONGS THE ACTION OF INSULIN.

ALLOPLRINCL POTENTIATES THE EFFECTS OF BISHYCROXYCCUMARIN, AND MERCAPTCPURINE. IT MAY INCREASE HEPATIC IRCN CONCENTRATION.

ANTACIDS CONTAINING DIVALENT AND IRIVALENT CATIONS DECREASE CRAL ABSCRPTION OF TETRACYCLINES. AFTACIDS SHOULU NOT BE ADMINISTERED SIMULTANEOUSLY WITH ENTERIC CCATED PRGDUCTS. SCOIUM POLYSTYRENE RESIN (KAYEXALATE) BINOS MAGNESIUM AND CALCTUM IONS FOUND IN ANTACICS RESULTING IN SYSTEMIC ALKALOSIS.

AMANTACINE (SYMMETKEL) POTENTIATES THE PHARMACQLGGICAL EFFECTS PROCUCEC BY LEVUCUPA.

AYINOPHYLLIN MAY IMPAIR THE THERAPEUTIC RESPONSE TO LITHIUM CARBUNATE EY INCREASING THE RENAL EXCRETICN OF LITHIUM IONS. 
AMINCSALICYLIC ACID PLASMA LEVELS ARE ELEVATED BY PROBENECID (BENEMID) AMMONIUM CHLORIDE (URINARY ACIDIFIER) MAY DECREASE RENAL REABSORPTION DF AMPHETAMIRES ANO TRICYCLIC ANTIDEPRESSANTS.

AMPHOTERICIN E (FUNGIZONE) MAY PRDOUCE HYPGKALEMIA PRECIPITATING Digital IS TOXICITY. It MAY POTENTIATE NEUROMUSCLLAR BLoCKAdE of SKELETAL MUSCLE RELAXANIS.

AMPICILLIA PLASMA LEVELS ARE INCREASED BY CONCOMITANT USE GF PROBENECIO (EENEMIL).

AMPHETAMINES PGTENTIATE maOI aNO ANTAGQNizE THE EFFECTS OF GUANETHIDINE. PHENOTHIAZINES MAY ANTAGONIZE THE CENTRAL EFFECIS OF AMPHETAMINES. URIAE ACIOIFYING AGENTS DECREASE RENAL REABSORPIION AND URINARY ALKALINIZERS SUCH AS ACETAZOLAMIDE (DIAMGX), SODIUM BICARBONATE AND THIAZIDE CIURETICS INCREASE REABSORPTION.

ANGIOTENSIN AMIDE (HYPERTENSINI-INDUCED ANTICIURESIS AND ANTINATRIURESIS IS REVERSED BY ETHACRYNIC ACID (EDECRIN) AND FUROSEMIDE (LASIX).

ANABGLIC STEROIOS MAY POTENTIATE THE ACTIVITY OF ORAL ANTICOAGULANTS, PHENYLBUTAZOAE (BUTAZOL IOIN) ANE OXYPHENBUTAZCNE (TANDEARIL). THEY MAY DECREASE INSLLIN REQUIREMENTS IN DIABETICS.

ANTICHOL INERGIC DRUES MAY POTENTIATE QUINIDINE AND THE SECCNOARY PHARMACOLGGICAL EFFECTS OF ANTIHISTAMINES AND TRICYCLIC ANTIDEPRESSANTS. PROPRANCLGL IINOERALI-INOUCED ADVERSE EFFECTS ARE ANTAGONIZED BY ANTICHOLINERGICS. THEY MAY PRODUCE EXTRAPYRAMIDAL SYMPTOMS THEN USED SIMULTANEOUSLY WITH METHOTRIMEPRAZINE (LEVOPRUME). 
oral ant ICOAGULANTS ARE POTENTIATEC BY ACETANINOPHEN, ESTRGgens, ANAECLIC STEROIDS, CHLORAMPHENICOL, CHOLESTYRAMINE (CUEMIU), CLOFIBRATE (ATREMID S), D-THYROXINE, PHENYLEUTAZONE (BUTAZCLIDINI AND PHENYRAMIDOL (ANALEXIN). THEy maY BE pOTENTIATEO BY AMINOGLYCOSIDE ANTIBIOTICS, DIPHENYLHYDANTCIN, INDOMETHACIN, GUINIDINE AND SALICYLATES. THEY ARE ANTAGONIZED EY ETFYL ALCCHDL, BARBITURATES, ETHCHLDRVYNOL, GFISEOFULVIN AND GLUTETHIMIDE. THEY ARE VARIABLY AFFECTEO QY CHLCRAL HYDRATE.

TRICYCLIC ANTIDEPRESSANTS MAY POTENTIATE THE ADVERSE EFFECTS OF MAOI ANU ETHYL ALCOHCL ANO THE PHARMACOLOGICAL EFFECTS OF SYMPATHOMIMETICS, THYROIO PREPQRATIONS, ANTIHISTAMINES AND ANTICHOLINERGICS. THEY MAY ANTAGONIZE GUANETHIDINE. BARBITURATES APPEAR TO DECREASE THERAPEUTIC ACTIVITY. THEY ARE POTENTIATED BY METHYLPHENIDATE. URINE ACIDIFYING AgENTS CECREASE RENAL REABSORPTION AND LRINE ALKALINIZING AGENTS INCREASE REABSORPTION.

ANTIHISTANINES MAY PRODUCE ACDITIVE CNS DEPRESSANT EFFECTS WHEN USED CONCOMITANTLY WITH ETHYL ALCOHOL, BARBITURATES ANO PHENOTHIAZINES. THEY MAY POTENTIATE THE PHARMACOLOGICAL ACTIVITY OF ANTICHOLINERGICS AND THE ACVERSE EFFECTS GF TRICYCLIC ANTIDEPRESSANTS.

ANTIHYPERTENSIVE AGENTS MAY BE POTENTIATED BY METHUTRIMEPRAZINE ILEVCPROME), PROCAINAMIDE (PRONESTYL) AND PROPRANOLOL (INDERAL).

ASCORBIC ACID (URINARY ACIOIFIER) MAY ANTAGONIZE AMPHETAMINES AND TRICYCLIC ANTIDEPRESSANTS. 
BARBIURATES-ADDITIVE EFFECTS MAY BE SEEN WITH THE CONCOMITANT USE OF ANTIHISTAMINES, PHENOTHIAZINES AND CTHER CNS DEPRESSANTS. THEY MAY BE

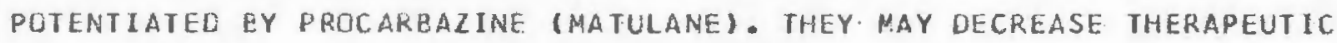
EFFECTS OF CRAL ANTICOAGULANTS, TRICYCLIC ANTICEPRESSANTS AND GRISEOFULVIN. THEY MAY. VARIABLY EFFECT SERUM DIPHENYLHYDANTCIN LEVELS.

BISHYDRCXYCDUMARIN MAY POTENTIATE THE SULFONYLUREAS AND INCREASE SERUM LEVELS OF DIPHENYLHYDANTOIN. IT IS POTENTIATED BY ACETAMINOPHEN, ESTROGENS, ANAQDLIC STEROIDS, CHLORAMPHENICOL, CHOLESTYRAMINE (CUEMID), CLDFIBRATE (ATROMID S), D-THYROXINE, PHENYLQUTAZONE (BUTAZOLIDIN) AND PHENYRAMIDOL (ANALEXIN). IT MAY be POTENTIATEO BY AMINOGLYCOSIDE ANTIBIOTICS. DIPHENYLHYCANTCIN, INDOMETHACIN AND SALICYLATES. IT IS ANTAGONIZED BY ETHYL ALCOHOL, BARBITLRATES, ETKCHLORVYNOL, GRISEOFULVIN AND GLUTETHIMIDE. IT IS VARIABLY AFFECTED BY CHLURAL HYORATE.

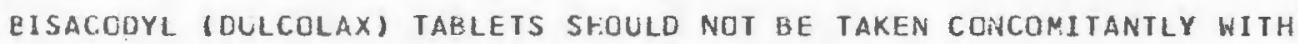
ANTACIOS.

CALCIUM ICNS ADMINISTERED PARENTERALLY MAY PHARMACOLCGICALLY POTENTIATE DIGITALIS GLYCOSIDES.

CARBENICILL IN IPYOPEN, GEUPEN) PLASHA LEVELS MAY BE ELEVATED AND PRDLONGED BY PRCBENECID (BENEMID).

CEFHALOSPCRINS, ALL-PLASMA LEVELS ARE ELEVATED BY PROBENECID (BENEMID). CONCONITANT ADMINISTRATION OF CEPHALOTHIN ANO COLISTIN INCREASES INCIDENCE CF NEPHRGTOXICITY. 
CHLORAL BETAINE (BETA-CHLOR) VARIABLY EFFECTS THE ANTICOAGULANT RESPONSE TO CRAL ANTICOAGULANTS.

CHLDRAL HYORATE VARIABLY EFFECTS THE ANTICCAGULANT RESPONSE TO ORAL ANTICOAGULANTS.

CHLORAMPHENICOL MAY POTENTIATE ORAL ANTICOAGULANTS, DIPHENYLHYOANTOIN AND SULFONYLLREAS.

DIURETICS FRDCUCING POTASSIUM AND MageSIUM DEFICIENCIES MAY PRECIPITATE DIGITALIS TOXICITY. CONCOMITANT USE WITH CCRTICOSTEROIDS MAY RESULT IN EXCESSIVE POTASSIUM LOSS. DIURETICS MAY ANTAGONIZE THE ACTIVITY DF ORAL HYPOGLYCEMICS.

CHCLESTYRAMINE (CUEMID) MAY ELEVATE THE ANTICDAGULANT RESPCNSE TO ORAL ANTICOAGULANTS. IT DECREASES ABSORPTION DF THYROID PREPARATIONS BY BINCING THYRCXINE AND TRIIODOTHYRCNNINE.

CLOFIBRATE (ATROMIO S) PHARMACOLCGICALLY ELEVATES THE ANTICOAGULANT RESPONSE TO CRAL ANTICOAGULANTS. IT MAY INHIB.IT PLATELET AUHESIVENES5.

COLISTIN (COLIMYCIA) ENHANCES NELRGMUSCLLAR BLGCKADE OF SKELETAL MUSCLE RELAXANTS. CCNCGMITANT AOMINISTRATICN CF PARENTERAL CEPHALCSPCRINS INCREASES INCICENCE OF NEPHROTOXICITY.

CGRTICOSTEROIDS MAY BE PUTENTIATED BY ESTROgENS. THEY NAY PHARMACOLOGI-

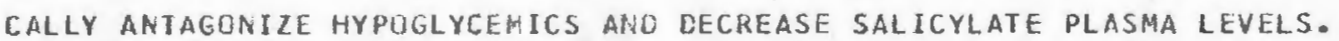
DIPHENYLHYCANTOIA MAY DECREASE THERAPEUIIC RESPONSE TO CORTICCSTEROIOS. CONCOMITANT LSE RITH OIURETICS MAY RESLLT IN EXCESSIVE POTASSIUM LOSS. 
CORTICQTRCPIN (ACTH) MAY BE POTENTIATED BY ESTROGENS. IT MAY PHARMACCLOGICALLY ANTAGONIZE HYPOGLYCENICS AND DECREASE SALICYLATE PLASMA LEVELS. CIPHENYLHYOANTOIN MAY DECREASE RESPONSE TO CORTICOSTEROIOS. CONCOMITANT USE WITH DIURETICS MAY RESULT IN EXCESSIVE PCTASSIUM LOSS.

DAPSONE (AVLOSULFCN) PLASMA LEVELS ARE INCREASED BY PROBENECID (BEAEMIO).

DIGITALIS gLYCOSIDES ARE PHARMACOLGgICALLY PCTENTIATED BY PARENTERAL CALCIUM PREPARATIONS ANND DIURETICS PRODUCING POTASSIUM AND MAGNESIUM DEFICIENCIES. AHPHOTERICIN B (FUNGIZONE) MAY PRODUCE HYPOKALEMIA PRECIPITATING LIGITALIS TOXICITY. SYMPATHOMIMETICS MAY INCREASE INCICENCE DF CAROIAC ARRTYTHMIAS.

EIPHENYLHYDANTUIN IS POTENTIATEO EY CHLORAMPHENICOL, DISULFIRAM (ANTABUSE) AND ISONIAZID. IT MAY BE ANTAGONIZED BY ETHYL ALCOHOL ANO PHENYRAMIDOL (ANALEXIN). IT MAY POTENTIATE ORAL ANTICOAGULANTS AND METHOTREXATE. It MAY EECKEASE the THERAPEUTIC RESPONSE TO CGRTICOSTEROIDS. CIPYRIDAMCLE (PERSANTINE) MAY POTENTIATE THE ANTICOAGULANT ACTIVITY CF HEPARIN.

CISULFIRAN (ANTABUSE) POTENTIATES DIPHENYLHYOANTOIN. CONCOMITANT USE WITH ISONIAZIO, ETHYL ALCUHOL AND METRONIOAZOLE (FLAGYL) ENHANCES THE INCIDENCE DF ADVERSE EFFECTS.

ECHOTHIOPFATE IODIDE (PHOSPHCLINE IODIDE) POTENTIATES THE PHARMACQLOGICAL EFFECTS CF SUCCINYLCMOLINE. 
EPHEDRINE POTENTIATES HYPERTENSIVE REACTIONS WITH MACI I IT ANTAGONIZES THE ACRENERGIC NEURON BLOCKACE PRODUCED BY GUANETHIDINE (ISNELIN).

EPINEPHRIAE, AND TO A LESSER EXTENT, OTHER ADRENERGIC AGENTS MAY DECREASE ACTIVITY OF HYPOGLYCEMIC AGENTS.

ESTROGENS PHARMACOLOGICALLY ELEVATE THE ANTICCAGLLANT ACTIVITY OF ORAL ANTICOAGLLANTS. THEY NAY POTENTIATE CORTICOSTERCID ACTIVITY.

ETHACRYNIC ACID POTENTIATES CTOTOXICITY OF AMINOGLYCOSIDE ANTIBIOTICS. 17 NAY PRODUCE POTASSIUM AND MAgAESIUM DEFICIENCIES PRECIPITATING DIGITALIS TOXICITY. CONCOMITANT USE WITH CORTICCSTEROIDS MAY ENHANCE POTASSIUM LUSS. IT MAY ANTAGONIZE THE ACTIVITY GF DRAL HYPOGLYCEMICS.

ETHCHLORYYNCL (PLACIDYL) ANTAGONIZES THE ANTICOAGULANT ACTIVITY OF ORAL ANT ICEAGULANTS.

FOLIC ACIC ANTAGQNIZES THE ANTINEOPLASTIC ACTIVITY OF METHCTREXATE.

FUROSEMIDE MAY PRODUCE POTASSILM AND MAGNESIUM DEFICIENCIES PRECIPITAIING DIGITALIS TOXICITY. CONCOMITANT USE WITH CCRTICOSTEROIDS MAY ENHAFCE pOTASSIUM LOSS. IT ENHANCES THE EFFECTS OF TUBOCLRARINE. IT MAY ANTAGONIZE THE ACTIVITY OF CRAL HYPOGLYCEMICS.

GENTAMICIN IN COMBINATION WITH OTHER AMINOGLYCOSIDE ANTIBIOTICS INCREASES INCICENCE OF CTOTOXICITY AND NEPMROTOXICITY. ETHACRYNIC ACID POTENTIATES THE GTOTOXICITY. IT ENHANCES THE BLCCKADE GF SKELETAL MUSCLE RELAXANTS. 
GLUTETHIMIDE (DORIDEN) DECREASES ANTICOAGULLANT RESPONSE TO ORAL ANT ICCAGULANTS.

gLyCERYL guaiacolate may pgtentiate the ant ICCAGULANT aCtivity of HEPARIN.

GRISEOFULVIN MAY DECREASE THE ANTICOAGULANT ACTIVITY CF ORAL ANTICOAGULANTS. IT IS ANTAGCNIZED BY BARBI TURATES WHICH MAY IMPAIR ABSORPTION.

EUANETHLOINE MAY GE POTENTIAJEO BY PRCCAINAMIDE, PROPRANOLCL AND GUIRJUINE. IT IS ANIAGONIZED BY AMPHETAMINES, TRICYCLIC ANTIDEPRESSANTS, EPHEDRINE ANC METHYLPHENIDATE. It MAY POTENTIATE PHENYLEPHRINE AND DECREASE ACTIVITY OF HYPOGLYCEMICS. ETHYL ALCOHOL AND METHOTRIMEPRAZINE (LEVOPROME), PROCARBAZINE (MATULANE) AND THIAZIDE DIURETICS MAY POTENTIATE CRTHCSTAIIC TYPOTENSION.

HEPARIN INCUCED ANTICOAGULANT ACTIVITY MAY BE ENHANCEO BY DIPYRIDAMULE (PERSANTINE) AND GLYCERYL GUAIACDLATE.

CRAL HYPEELYCEMIC AGENTS MAY BE POTENTIATED EY CHLORAMPHENICGL, MAOI, PHEAYLBUTAZONE (BUTAZULIDIN), PROPRANGLCL (INDERAL), GISHYDROXYCOUMARIN, PHENYRAMIDOL (ANALEXIN) AND SALICYLATES. THE HYPCGLYCEMIC EFFECTS ARE ANTAGUNIZEO BY CCRTICCSTEROIDS, DIURETICS AND GUANETHIDINE (ISMELIN).

INDOMETHACIN MAY PHARMACOLOGICALLY ELEVATE THE ACTIVITY CF ORAL ANTI COAGLLANTS. INDOMETHACIN PLASMA LEVELS MAY BE INCREASED BY PROBENECID (BEREMID) ANL CECREASED BY SALICYLATES. 
INSUL IN MAY BE PHARMACOLOGICALLY ANTAGONIZEQ BY GUANETHIDINE. ETHYL ALCCHCL MAY PROLONG THE ACTION OF INSULIN. GLUCOCORTIGOIDS, THYROID, EPINEPHRINE AND THIAZIDE DIURETICS MAY INCREASE INSUL IN REQUIREMENTS.

IRON SALTS SHOLLO NOI BE USEO SIMULTANEGUSLY HITH ALLOPURINOL (ZYLOPRIM). ANTAGIDS MAY DECREASE IRON ABSORPTION. IRON SALTS MAY IMPAIR THE ABSORPTICN GF ORAL TETRACYCLINES.

ISONLAZID INGREASES PLASMA LEVELS OF CIPHENYLHYDANTOIN. IT MAY BE ANTAGONIZEO EY ETHYL ALCOHOL. CCNCOMITANT USE HITH DISULFIRAM (ANTA8USE) AND MEPERTOINE ENHANCES INCIDENCE OF ADVERSE EFFECTS.

D-THYRoXIRE elevates the ANTICOAgulant response to oral anticoagulants. ISOPROTERENCL IS PHARMACOLGGICALLY AITAGONIZED BY PROPRANDLOL (INDERAL) KANAFYCIN IN CCMBINATICN WITH GTHER AMINDGLYCCSIDE ANTIBICTICS INCREASES INCICENCE OF CTOTCXIGITY AND NEPHROTOXICITY. CONCOMITANT USE WITH ETHACFYAIC ACID POTENTIATES THE OTCTOXICITY. It POTENTIATES NEUROMUSCULAR BLOCKADE OF SKELETAL MUSCLE RELAXANTS. hHEN ADMINISTERED BY THE ORAL ROUTE IT MAY INCREASE THE ACIIVITY CF ORAL ANTICOAGULANTS.

KAOL IN-PECTIN MIXTURES INHIBIT THE ABSORPTION DF ORALLY ADMINISTERED LINCOMYCIN (LINCGCIN).

LEVODOPA NAY BE ANTAGONIZED BY METHYLDOPA, PYRIDOXINE, RESERPINE AND PHENCTHIAZINES. CONCOMITANT USE WITH MAOI MAY PRCDUCE HYPERTENSION. ADDITIVE THERAPEUTIC EFFECTS MAY CCCUR WITH AMANTADINE (SYMMETREL). 
LITHIUM EXCRETIUN IS INCREASED BY AMINOPHYLLINE, SODIUM BICARBONATE AND LARGE DOSES CF SCDILM CHLORIDE. LCH SODIUM INTAKE MAY PRECIPITATE LITHIUM TOXICITY.

magnesium IONS administered parenterally potentiate the neurtmuscular BLOCKAUE OF SKELETAL MUSCLE RELAXANTS.

MEPERIDINE SHCULD NOT BE USED SIMULTANECUSLY WITH ISUNIAZID AND MAOIIT ENHANCES INCIDENCE OF ALVERSE EFFECTS. IT IS POTENTIATED BY CTHER CNS DEPRESSANTS.

NEPRCBAMATE (EQUANIL, MILTOWN IS POTENTIATED BY ETHYL ALCOHOL.

MERCAPTOPURINE (PURINETHOL) IS POTENTIATED BY ALLOPURINOL (ZYLOPRIM).

metaramincl (aramine) is pharmacologically pCTENTIATEd ey madi.

METHENAMIAE CGMPCUNOS EXHIBI I GPIIMUM ACTIVITY IN A URINE PH OF 5.5 CR LOWER. URINE ACIDIFYING AGENTS ARE USEFUL ADJUNCTS WHILE URINE ALKALINIZERS DECREASE ACTIVITY. CONCOMITANT USE WITH SULFONAMIDES FREQUENTLY, RESULTS IN CRYSTALLURIA AND THE FGRMATICN OF A PRECIPITATE.

METHCTREXATE SERUM LEVELS ARE ELEVATED BY DIPHENYLHYDANTOIN, SALICYLATES AND SULFONAMIDES. IT MAY IMPAIR THE IMMUNOLOGICAL RESPONSE IC SMALLPOX VACCINE, RESULTING IN VACCINA.

METHCTRIMEPRAZINE (LEVOPROME) POTENTIATES THE EFFECTS OF ANTIHYPERTENSIVE AGENTS, OTHER CNS DEPRESSANTS AND SKELETAL MUSCLE RELAXANTS. IT WILL PRODUCE EXTRAPYRAMIDAL SYMPTOMS WHEN USED SIMULTANEOUSLY WITH AAT ICHOL INERGICS. 
METHYOXYFLURANE ANESTHESIA IN CONJUNCTION WITH TETRACYCLINE IHERAPY INCREASES INCICENCE OF NEPHROTOXIC EFFECTS.

METHYLDOPA MAY ANTAGCNILE THE THERAPEUTIC EFFECTS OF LEVODCPA. ACDITIVE HYPCTENSIVE EFFECTS MAY OCCUR WITH PROPRANOLOL (INDERAL), PROCAINAMIDE (PRONESTYL), METHOTKIMEPRAZINE (LEVGPROME) AND THIAZIDE DIURETICS.

METHYLPHEAICATE IRITALIN) POTENTIATES TRICYCLIC ANTIDEPRESSANTS. IT MAY

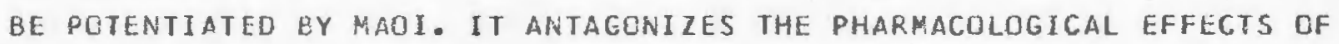
GUANETHIOINE (ISNELIN).

METRENIDAZCLE IFLAGYLS SHOLLD NOT BE USED SIMULTANEOUSLY WITH CISULFIRAN (ONTAEUSE) OR ETHYL ALCOHOL DUE TO THE INCREASED INCIDENCE OF ADVERSE EFFECTS.

MONOAMINE OXICASE INHIBITORS POTENTIATE THE PHARMACULOGICAL EFFECTS CF AMPHETAMINES, METHYLPRENIDATE (RITALIN), TRICYCLIC ANTIDEPRESSANTS, HYPGGLYCEMICS ANE SYMPATHGMIMETICS SUCH AS EPHEDRINE, METARAMINOL (ARAMIAE), PHENYLEPHRINE AND PHENYLPROPANOLAMINE. CONCOMITANT USE WITH MEPERIDINE OR LEVCDOPA INCREASES INCIDENCE CF ADVERSE EFFECTS.

MAFCILLIN (UNIPEN) PLASMA LEVELS ARE INCREASED BY CONCONITANT USE OF PROEENECIC (PENEMID).

NEOMYCIN IN COMBINATION WITH OTHER AMINUGLYCOSIDE ANTIBIOTICS INCREASES INCICENCE OF OTOTOXICITY AND NEPHROTOXICITY. CONCDMITANT USE WITH ETHACRYNIC ACID POTENTIATES THE OTOTOXICITY. IT POTENTIATES NEUROMUSCULAR BLOCKADE OF SKELETAL MUSCLE RELAXANTS. KHEN AOMINISTERED gY THE ORAL ROUTE It MAY INCREASE THE ACTIVITY GF ORAL ANTICOAGULANTS. 
NITROGLYCERIN MAY PRCOUCE HYPETENSICN FCLLCWING COMBINEC USE WITH ETHYL ALCOHOL. CHRCNIC ACMINISTRATION OF PENTAERYTHRITOL TETRAMITRATE IPERITRATE) MAY PROLUCE A TOLERANCE TO NITRCGLYCERIN.

CRPHENACR INE (NORFLEX) IN COMBINATION WITH PROPOXYPHENE (DARVON) MAY PRODUCE MENTAL CONFUSION AND ANXIETY.

OXYPHENBUTAZONE (TANDEARIL) ELEVATES THE ANTICOAGULANT RESPONSE TO ORAL ANTICOAGLLANTS. OXYPHENBUTAZONE PLASMA LEVELS MAY BE ELEVATED BY ANABOL IC STEROIOS.

PENICILLIN G AND DER IVATIVES-PLASMA LEVELS ARE ELEVATED BY PROBENECID (BENEMID) AND SALICYLATES.

PENTAERYTRRITOL TETRANITRATE (PERITRATE) THERAPY MAY PRGDUEE A TOLERANCE TO NITRCGLYCERIN.

PhENOTHIAZINES MAY aNTAGONIZE LEVODCPA AND THE CENTRAL EFFECTS OF AMPHETAMINES. ADDITIVE EFFECTS CCCUR WITH CONCOMITANT USE OF DTHER CNS CEPRESSANTS AND ANTIHISTAMINES. ADDITIVE CARDIAC DEPRESSANT EFFECTS ARE PCSSIBLE HITH QUINIOINE. PROCARBALINE (MATULANE) MaY putentiate the CNS CEPRESSANT EFFECTS OF PHENOTHIAZINES.

phenylbutazcne (OUTAzolioIn) elevates the anticoagulant response to oRAL ANTICOAGULANTS AND POTENTIATES THE HYPOGLYCEMIC RESPONSE TO SULFONYLureas. phenyleutazche plasma levels may be elevated by ainabclic steroids. PHENYLEPHRINE AUMINISTERED NASALLY OR SYSTEMICALLY MAY BE POTENTIATED BY GUANETHIDINE IISHELIN) AND MAOI. 
PHENYLPROPANOLAMINE MaY Be POTENTIATED by MaOI.

PHENYRAMICOL (ANALEXIN) ELEVATES THE ANTICOAGULANT RESPGNSE TO ORAL ANTICOAGULANTS AND POTENTIATES THE ACTIVITY OF DIPHENYLHYDANTOIN ANO SULFONYLUREAS.

POLYMYXIN B (AERCSPCRIN) ENHANCES NEURGHUSCULAR BLCCKACE OF SKELETAL MUSCLE RELAXANTS. IN CONGINATION WITH OTHER AMINOGLYCOSIDE ANTIBIOTICS IT INCREASES INCICENCE CF OTOTOXICITY AND NEPHROTOXICITY.

PROBENECIT (BENEMID) ELEVATES PLASHA LEVELS UF AMINOSALICYLIC ACID, DAPSONE (AVLCSULfON), CEPHALOSPCRINS, PENICILlin g aND DERTVATIVES AND I NOCMETHACIN * SALICYLATES INHIBIT URICCSURIC ACTIVITY OF PROBENECID.

PROCAINAMIDE (PRONESTYL) - ADOITIVE HYPOTENSIVE EFFECTS MAY OCCUR WITH CONCOMITANT USE CF ANTIHYPERTENSIVE AGENTS.

procarbazine (hatulane) may potentiate the effects of phendthiazines AND CNS EEPRESSANTS. IT MAY PRODUCE ADDITIVE HYPDTENSIVE EFFECTS WITH GUANETHIDINE (ISMELIN):

PROPOXYPHENE (DARVCN) IN COMBINATION WITH CRFHENADRINE (NORFLEX) MAY PROCUCE MENTAL CCNFUSIUN AND ANXIETY.

PROPRANCLCL (INDERAL) NAY POTENTIATE ORAL HYPCGLYCEMICS AND ANTIHYPERTENSIVES. IT ANTAGONIZES PMARMACULCGICAL ACTIONS OF SYMPATHOMIMETICS. FROPRANCLOL-INCUCED ADVERSE EFFECTS ARE ANTAGCNIZED BY ANTICHOLINERGICS. ACDITIVE CARCIAC DEPRESSANT EFFECTS ARE POSSIBLE WITH QUINIDINE ANO PHENOTHIAZINES. 
PYRIDOXINE (VITAMIN BG) ANTAGONIZES THE PHARMACOLOGICAL EFFECTS OF LEVCUCPA.

GUINIDINE MAY POTENTIATE GUANETHIOINE, URAL ANTICOAGULANTS AND THE AEURCNUSCULAR BLockade of MUSCLE RELAXANTS. IT MAY BE POTENTIATEO BY ANTICHOL INERGICS. ACETAZOLAFIDE (DIAMCX), SCOIUM gICARBCNATE aNO THIAZIDE CIURETICS INCREASE RENAL REAGSORPTION. ADUITIYE CARDIAC DEPRESSANT EFFECTS ARE POSSIBLE WITH PROPRANOLOL.

FESERPINE IS POTENIIATED BY METHOTRIMEPRAZINE (LEVOPROME). IT MAY AATAGONIZE THE EFFECTS OF LEVUOCPA.

SALICYLATES ELEVATE THE ANTICOAGULANT RESPONSE TO ORAL ANTICCAGULANTS, INCREASE PLASMA LEVELS OF UNBCUND PENICILLIN G AND DERIVATIVES AND potentiate methotrexate and SUlfonylureas. Salicrlate plasma leVEls hay BE DECREASED BY CORTICOSTEROIDS. THEY MAY DECREASE SERUM LEVELS OF INCOMETHACIA (INCOCIN) ANC INHIBIT LRICCSURIC ACTIVITY OF SULFINPYRAZONE (ANTURANE) ARD PRUEENECIO (BENEMID).

SURGICAL SKELETAL NUSCLE RELAXANTS ARE POTENTIATED By AMINDGLYCOSIDE ANTIBIOTICS, AMPHOTERICIN B, FUROSEMIDE, MAGNESIUM IONS, METHCTRIMEPRAZINE (LEVCPRCME), QUINIDINE AND THIAZIDE DIURETICS. ECHOTHIOPHATE ICDIDE POTENTIATES THE EFFECTS OF SUCCINYLCHOLINE.

SMALL POX VACCINATIGN MAY RESULT IN GENERALIZED VACCINA WITH CONCOMITANT USE DF METHCTREXATE. 
SGOIUM BICARBONATE ELEVATES SERUN LEVELS OF AMPHETAMINES, TRICYCLIC ANT ICEPRESSANTS AND QUINIDINE BY ENHANCING RENAL REABSORPTION. IT HAY ANTAGONIZE METHENAMINE COMPUUNDS AND LITHIUM CARBCNATE AND DECREASE CRAL ABSCRPTION OF TETRACYCLINES.

SUDIUN CHLORIDE. IN LARGE DOSES MAY ANTAGONIZE PHARMACOLOGICAL EFFECTS OF LITHIUH CARBOAATE. LCW SOQIUH INTAKE MAY PRECIPITATE LITHIUM TOXICITY. SCOIUM POLYSTYKENE SULFONATE RESIN (KAYEXALATE) BINOS MAGNESIUN ANO CALCIUM IOAS FOUND IN ANTACTUS RESULTING IN SYSTEMIC ALKALOSIS.

STREPTOMYCIN IN COHBINATION WITH AMINOGLYCOSIDE ANTIEIOTICS INCREASES INCIDENCE OF CTOTOXICITY ANO NEPHROIOXICLTY. ETHACRYNIC ACID POTENTIATES THE OTOTOXICITY. IT POTENTIATES NEURCMUSCULAR BLOCXADE OF SKELETAL MUSCLE RELAXANTS.

SULFINPYRAZGNE (ANTURANE) INCUCED URICOSURIA IS INHIBITED BY SAL ICYLATES.

SULFGNAMICES MAY PETENTIATE THE HYPOGLYCEMIC RESPONSE TO ORAL hyPQGLYCEMICS ANC ELEVATE SERUM LEVELS OF METHOTREXATE. CONCOMITANT USE WITH METHENAMINE COMPOUNCS FREQUENTLY RESULTS IN CRYSTALLURIA AND THE FCRMAT ION DF A PRECIPITATE.

TETRACYCLINE ABSCRPTION IS CECREASED BY ANTACIOS CONTAINING DIVALENT OR TRIVALENT CATIONS, SCOIUM BICARBONATE AND IRON SALTS. IT MAY ELEVATE ANT ICOAGULANT RESPONSE IO ORAL ANIICOAGULANIS AND POTENTIATE NEPHROTOXIC EFFECTS OF METHCXYFLURANE (PENTHRANE). 
THIAZIDE CIURETICS MAY PRECIPITATE DIGITALIS TOXICITY AND ANTAGONIZE THE EFFECTS OF HYPOGLYCEMICS. NELROMUSCULAR BLGCKADE PRCOUCEO BY SURGICAL MUSCLE RELAXANTS MAY EE ENHANCED. CCNCOMITANT USE HITH CORTICCSTEROIOS MAY RESULT IN EXCESSIVE PGTASSIUP LESS. THEY MAY PRDDUCE AOCITIYE HYPOTENSIVE EFFECTS WITH GUARETHIDINE (ISMELIN) ANO METHYLCOPA (ALDOMET).

THYROID PREPARATIONS MaY POTENTIATE the aNtICGAGllant RESPCNSE to ORAL ANTICOAGULANTS. CHOLESTYRAMINE DECREASES ABSORFTION BY BINDING THYROXINE ANC TKH IGDGTHYRONNINE. THEY MAY DECREASE ACTIVITY OF HYPOGLYCEMIC AGENTS: 
APPENDIX VI

Computer Program

$-111-$ 
LIAE NO. SES. NO.

OCIOIO LOENTIFICATION DIVISIUN.

OCIO20 PRUGRAM-IT. 'COTRPT'.

OO1030 ALTHOR. P E PLATIAU \& C DAHONEY.

$0 O 1040$ REMARKS. SAMPLE PROGRAM FOR RETRIEVAL DE DRUG-DQUG TNTERACTION

COLO5O SUMMARIES WI HH SAMPLE PROFILE.

CCIOEO EAVIRONMENT DIVISICN.

OCIOTO CONFIGURATIAN SECTION.

QO1080 SCURCE-COMPUTER: IAH-360 F30.

001090 OBJECT-COMPUTER. IBHA-360 E30.

OQI1GO IAPUT-OUTPUT SECTION.

001110 FILE-CONTRGE.

OCH120 SELECT CAROASSION TG ISYSOO4 UNIT-RECORO 25402.

OCI130 SELECT PRINT ASSIGN TC SYSOD5' UNIT-RECORO 1403.

OC1140 SELECT OISK ASSION TC 'SYSOI3. DIRECT-ACCESS 2314

OC1150 ACCESS IS RANDOM, ORGANIZATION IS INDEXEO,

OCL150 RESERVE NO ALTERNATE AREA, SYPBCLIC KEY IS REC-IO.

001170

OCZO10 DATA DIVISIUN.

OEZ020 FILE SECTIUN.

002030 FE CARO

002040 RECORC CONTAINS 30 CHARACTERS, LABEL RECORO IS UMITTEO,

002050 DATA RECURD IS CD, RECQRDING MODE IS F.

$002 C 60$ d1 CO.

002061 02 CD-IN PICTURE X(79).

002062 O2 CODE PICTURE $X$.

00206388 HED VALUE 'A'.

$002064 \quad 89$ MED VALUE. $B$ B'.

002065 38 DAT YALUE "C".

OC2070 FE. PRINT

002030 RECORO CONTAINS 133 CHARACTERS, LABEL RECORD IS TMITTED,

OC2090. DATA RCCQRD IS PRT, RECOROING MODE IS F.

OC2ICO O1 PRT PICTLRE X(I3).

$0 C 2110$ FD DISK

OC2120 RECORD CONTAINS 571 CHARACTERS, LABEL RECORD IS STANOARD, CC2130 DATA FECORD IS DSK, RECCRDING MODE IS F.

OC2140 Ol OSK.

OC2150 OL OSK-NG PICTURE $\times(5)$.

OC216C 02 MSG, OCCURS 9 TIMES.

OC2170 OJ DSK-NSG PICTLRE X1741.

003010 WORK1NG-S TORAGE SECT $10 N$.

$003020 \quad 77$ A PICTURE 59999

$\begin{array}{llll}003030 & 77 & B & \text { PICTLRE } 59997\end{array}$

$003040^{\circ}, 77 \mathrm{C}$. PIC TURE $\$ 9999$

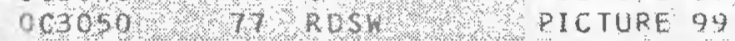

$003060 \quad 77$ LIN-CNT PICTURE 99

OC3070 $77 \mathrm{CC}$ PICTURE $X$.

OC3080 377 . PAG CNT. PICTURE 99

$0 \mathrm{C} 3090$ 77 NAME-STOR

PICTLRE X(21)

OC3100 77 PI-NII-STCR PICTURE $9(7)$

OC3110 77 PT-RM-STCR PICTURE $X X X$.

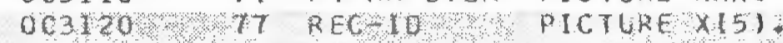

$003125 \% 77$ DAYSTOR PICTUREX.

OC 3130 OI TABLE.

CC3140 Q2 LIAE, CCCUKS 30 TIMES.

CONPUTATIONAL VALUE O. COMPUTATIONAL VALUE 0 . COMPUTATIONAL VALUE 0. CQMPUTATIONAL-3 VALUE 1 . COMPUTATILNAL - 3 VALUE 0.

CONPUTATIONAL-3NATUE O. COMPUTATIUNAL - 3 VALUE 0. 
IINE NO. SEQ NO.

SQURCE STATEMENT

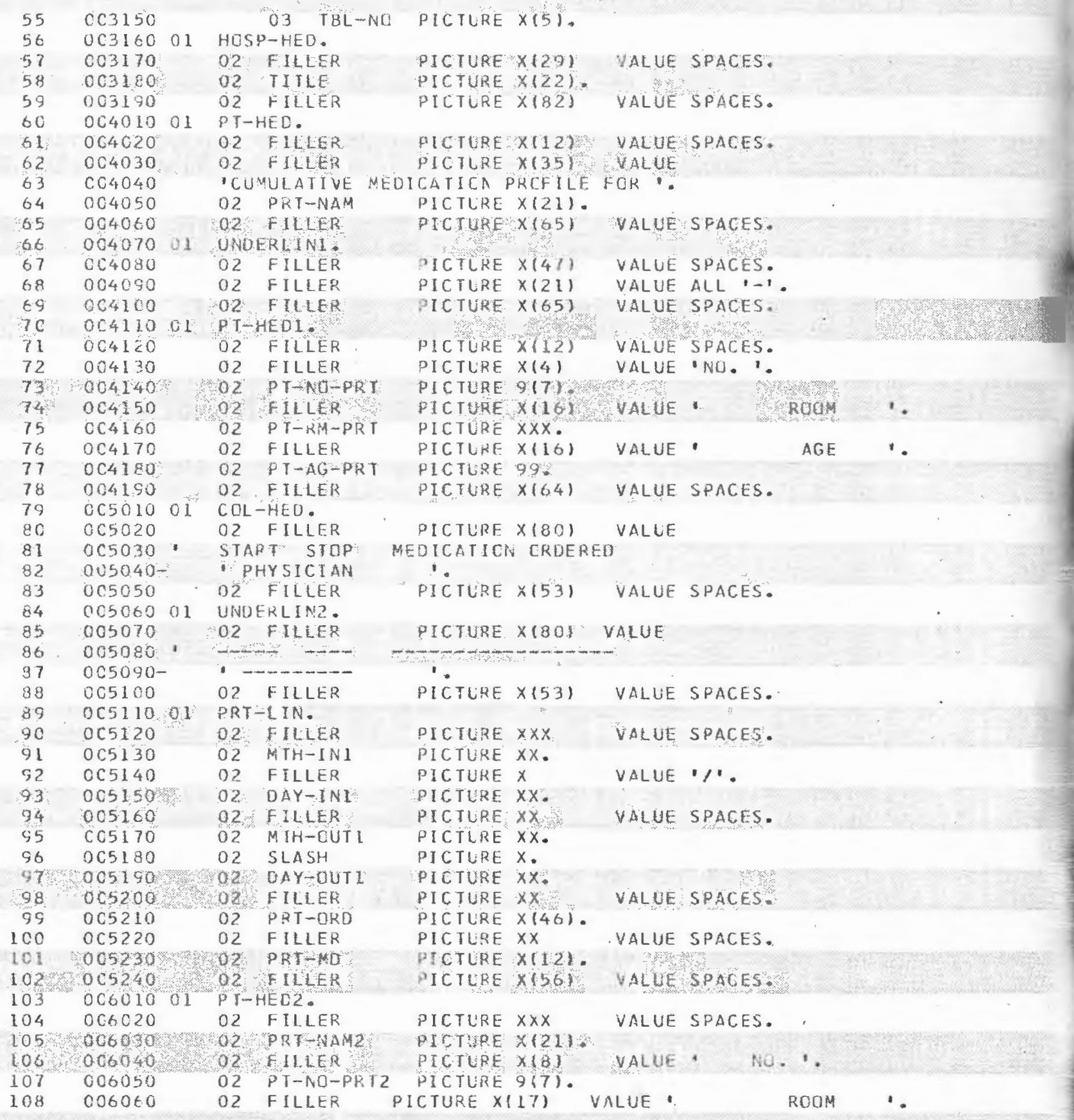


LINE NO . SEQ NO.

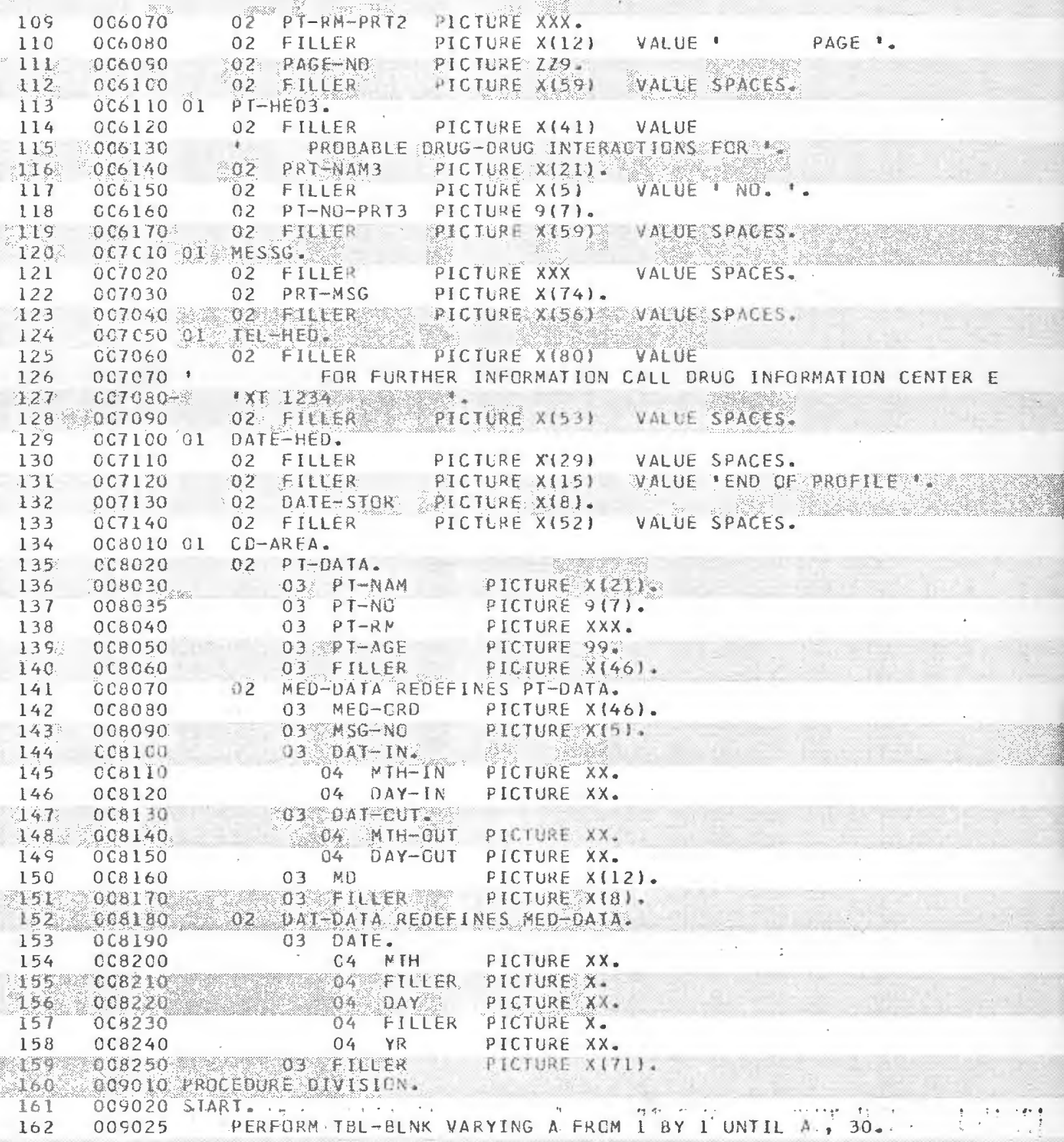


LINE NO . SEQ. NO.

164

165

166

167

168

169

170

171

172

173

174

175

176

177

178

179

180

181

182

183

184

185

186

187

189

L89

190

191

192

193

194

195

196

197

198

195

$20 \mathrm{C}$

201

202

$2 \mathrm{C} 3$

204

205

206

207

$2 \mathrm{Cg}$

209

210

211

212

213

214

215

216

$0 \mathrm{c} 9070$

005080

$0 \mathrm{col} 00$

009105

009110.

009115

c.c4120

OCs 130

009135

Cc9140

069150

009160

OCS180

010010

010020

010030

C 10040

010050

010060

010070 .

010080

010090

$0101 \mathrm{co}$

010110

010120

010130

C10140

010150

010160

010170

010175

011010

011015

011016

011020

011030

011040

C11050

C11070

011080

C 110 S0

011100

01110

011120

011130
SUURCE STATEMENT:

OPEN INPUT CARD DISK CUTPUT PRINT.

009040 CDRD.

CC9050 FEAD CARD AT END GO TO EOJ.

009055 MOVE CD-TN TOCEAREA.

009056 IF DAT GO TO DATE-SAV.

CC9060 IF RUSW = I GC TC FIRST-RTN.

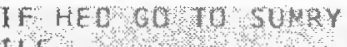

IF LIN-CNT, 26 PERFCRM HED-RINZ.

DOSOS5 MUVE MTH-IN TU HTH-INL. MOVE DAY-IN TO DAY-INI.

MOVE MED CRD TG PRT-CRD. MOVE MD TO PRT-MDV

IF DAY-OUT=, MOVE ,TO \$LASH ELSE MOVE M/ TO SLLSH

MEVE MTH-CUT TO MTH-CUTL. MUVE DAY-CUT TO DAY-OUTI.

PERFORM RITE-LINE. IF CAY-TUT $=$, GO TO CHK-RTN.

IF UAYOOU I DAY STCR GO TO CORO ELSE GOTROCHK-RTH.

RIE-LINE ? ? ? MOVE PRI-LIN TO PRT. PERFORM RITE-RTN. ADO I TO LIN-CNT.

CH'K-RTN:

IF MSG-NO -160 TC CORD.

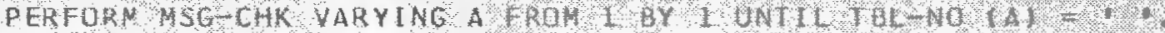
MUVE MSG-NO TO TBL-NC (A). GO TO CORO.

FIRST-RTN.

IF MEO GO TO CDRD. MEVE O TO ROSW:

PEREORM HED -RTNI. GE TOCLRO.

HED-RTN 1

MOVE 1 TO CC. MCVE ' MODERN HOSPITAL ' TO TITLE.

MOVE HOSP HHED TO PKT. PERFDR RITE-RTN. MOVE O TO CC.

MOVE TUEPARTMENT CF PHARHACY: TC TITLE. MUVE HOSP-HED TO PRT

PERFORM RI TE-RTN. MCVE PT-NAM TO PRT-AAM NAME-STOR.

MCVE PT-HED TO PRT. PEFFORM RITE-RTA. MDVE, TO CC.

MOVE UNCERLINI TO PRT. PERFORMARITE-RTN. MOVE O TOCC.

MOVE PT-NC TC PT-ND-STCR PT-NG-PRTO?

MOVE PT-RM TO PT-RM-STOR PT-RM-PRT.

MCVE PT-AGE TO PT-AG-PRT.

MGVE: PT-HEDI TO PHT. PERFCRN RTTE-RTN.

MOVE COL-HEO TO PRT. PERFQR RITE-RTN. MOVE, .TO CC

MOVE LNCERLINZ TO PRT. PEKFCR RITE-RTN -

MOVE O TO CC, A, B.

MOVESTOLIIN-CNT-MOVEL TO PAG-CN

HEO-RTN2

MUVE "CONIINUED UN NEXT PAGE TC TITLE MUVE HDSP HED TO PRT.

PERFQRM RITE-RTN.

MOVE IHTOCC. MOVE O.TC LIN-CNT.

MOVE NAME-STCR TO PRT-NAMZ.

MCVE PT-NC-STCR TO PT-NC-PRT2.

MOVE PT-RN-STCR TO PT-RM-PRT2.

ADD I TG PAG-CNT. MCVE PAG-CNT TO PAGE-ND.

HOVE PT-HED2 TO PRT. PERFORM RITE-RTH-MOVE $\mathrm{A}$ TO CC

MOVE 1 TO CC. MCVE O TL LINACNT.

MOVE PT-NO-STCR TO PT-NO-PRT3.

MUVE PT-RED3 TO PRT. PERFCRM RITE-RTM.

DATE-SAV. 


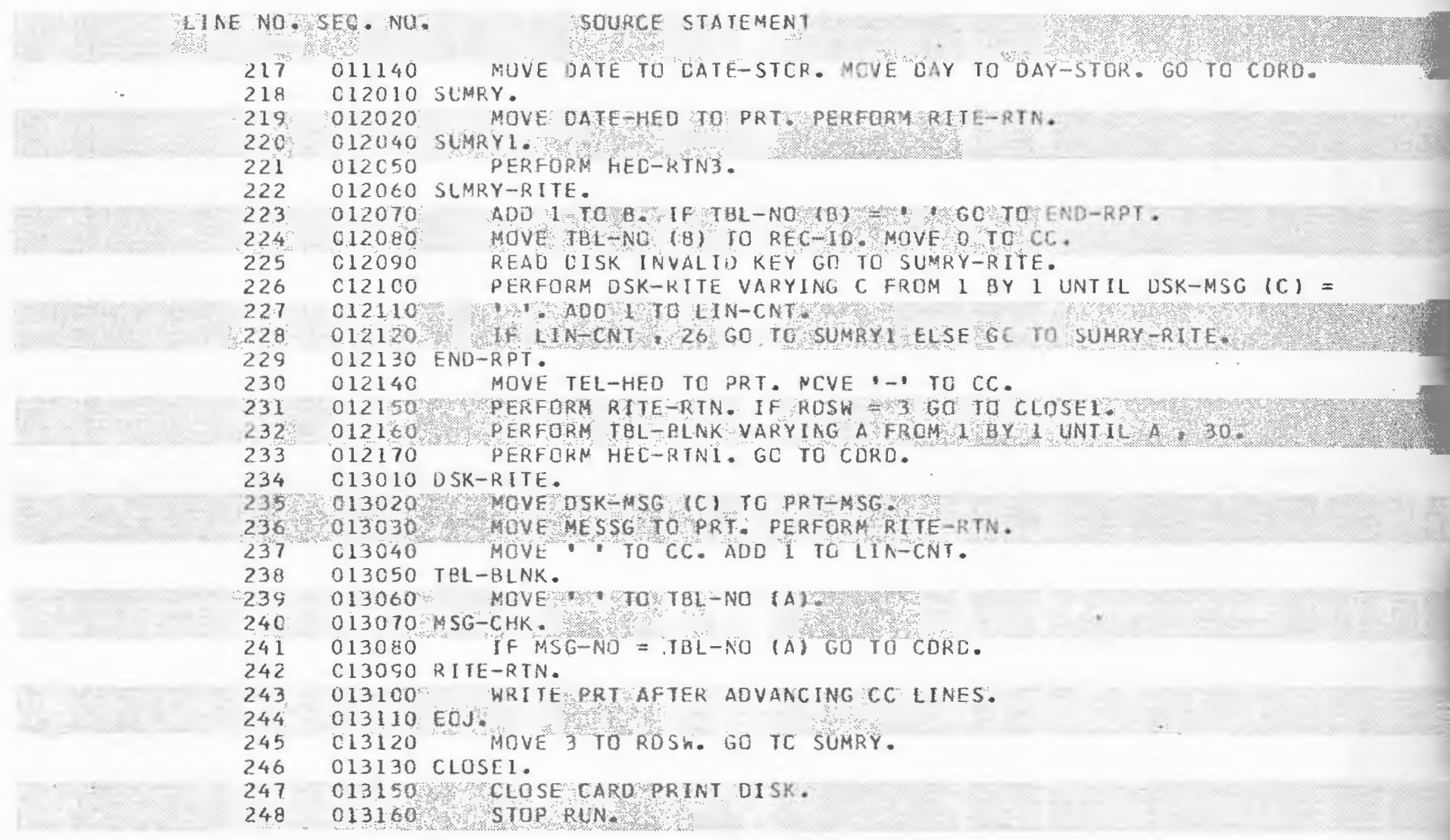

